\title{
RECONSTRUCTING THE EVOLUTION AND BIOGEOGRAPHIC HISTORY of tribe Cardueae (Compositae) ${ }^{1}$
}

\author{
Laia Barres ${ }^{2,7,8}$, Isabel Sanmartín ${ }^{3}$, Cajsa Lisa Anderson ${ }^{3,6}$, Alfonso Susanna ${ }^{2}$, \\ Sven Buerki ${ }^{3,4}$, Mercè Galbany-Casals ${ }^{5}$, and Roser Vilatersana ${ }^{2}$
}

\begin{abstract}
${ }^{2}$ Institut Botànic de Barcelona (IBB-CSIC-ICUB), Pg. del Migdia s.n., E-08038 Barcelona, Spain; ${ }^{3}$ Real Jardín Botánico (RJB-CSIC), Plaza de Murillo 2, E-28014 Madrid, Spain; ${ }^{4}$ Jodrell Laboratory, Royal Botanic Gardens, Kew, Richmond, Surrey TW9 3DS, United Kingdom; ${ }^{5}$ Unitat de Botànica, Dept. Biologia Animal, Biologia Vegetal i Ecologia, Facultat de Biociències, Universitat Autònoma de Barcelona, E-08193 Bellaterra, Spain; and ' ${ }^{6}$ epartment of Plant and Environmental Sciences, University of Gothenburg, Box 461, 45030 Göteborg, Sweden
\end{abstract}

- Premise of the study: Tribe Cardueae (thistles) forms one of the largest tribes in the family Compositae (2400 species), with representatives in almost every continent. The greatest species richness of Cardueae occurs in the Mediterranean region where it forms an important element of its flora. New fossil evidence and a nearly resolved phylogeny of Cardueae are used here to reconstruct the spatiotemporal evolution of this group.

- Methods: We performed maximum parsimony and Bayesian phylogenetic inference based on nuclear ribosomal DNA and chloroplast DNA markers. Divergence times and ancestral area reconstructions for main lineages were estimated using penalized likelihood and dispersal-vicariance analyses, respectively, and integrated over the posterior distribution of the phylogeny from the Bayesian Markov chain Monte Carlo analysis to accommodate uncertainty in phylogenetic relationships.

- Key results: The phylogeny shows that subtribe Cardopatiinae is sister to the remaining subtribes, and subtribes Carlininae and Echinopsinae appear as consecutive sister-clades to the Carduinae/Centaureinae. Tribe Cardueae is inferred to have originated around the Mid Eocene in West Asia, which is also the ancestral area of most subtribes within Cardueae. Diversification within each subtribe began during the Oligocene-Miocene period.

- Conclusions: Most diversification events within Cardueae are related to the continuous cycles of area connection and division between the Anatolian microplate and the western Mediterranean Basin during the Oligocene-Miocene and with the uplift of the Himalayan range from the Miocene onward. From these two regions, thistles dispersed and colonized the rest of the continents (e.g., the New World, Africa, and Australia), most likely during the colder Pliocene-Pleistocene period.

Key words: Bayes-DIVA; Bering Land Bridge; biogeography; Cardueae; Carduoideae; Himalayan uplift; Mediterranean Basin; molecular dating.

Thistles (tribe Cardueae) represent one of the largest tribes of the family Compositae, with over 2400 species distributed among 73 genera (Susanna and Garcia-Jacas, 2009). Cardueae are a common and essential element of the Mediterranean landscape (Quézel, 1978; Takhtajan, 1986), but they can also be found on other continents and ecosystems, such as steppes and semiarid environments. Of the four tribes comprising the subfamily Carduoideae, tribe Cardueae is the largest and the only one distributed worldwide, with representatives on every

\footnotetext{
${ }^{1}$ Manuscript received 3 February 2012; revision accepted 18 February 2013.

The authors thank the Ministry of Education and Science of the Spanish Government (projects CGL2006-01765/BOS and CGL2009-13322-C0303/BOS, CGL2009-13322-C03-01/BOS, CGL2010-18631 and grant BES2007-14260 to L.B.) and the Catalan Government ('Ajuts a grups consolidats' 2009/SGR/00439) for financial support. S.B. and C.L.A. were supported by postdoctoral grants at RJB from the Swiss National Science Foundation grant (PBNEP3-129903) and the Swedish Research Council, respectively. The authors also thank R. Bayer, M. Dematteis, V. Funk, D. Gutiérrez, D. Arredondo, M. Tobar, and T. Wendt, who kindly provided plant material.

${ }^{7}$ Author for correspondence (e-mail: laia.barres@gmail.com)

${ }^{8}$ Department of Plant and Environmental Sciences, University of Gothenburg, Box 461, 45030 Göteborg, Sweden
}

doi:10.3732/ajb.1200058 continent except Antarctica (Susanna and Garcia-Jacas, 2009). The remaining tribes, Dicomeae Panero \& V. A. Funk, Oldenburgieae, and Tarchonantheae, have a much less diverse distribution and are found exclusively in Africa (Ortiz et al., 2009). Until recently, Dicomeae, Oldenburgieae, and Tarchonantheae were included in tribe Mutisieae Cass. sensu Cabrera (1977) before being transferred to Carduoideae, based on new molecular and morphological evidence (Panero and Funk, 2008; Ortiz et al., 2009).

Cardueae include perennial, biennial, or monocarpic herbs and shrubs and, less often, annual herbs or small trees. The style is characterized in having the stigmatic areas confined to the inner surfaces of the style arms and an articulation below the branches of the upper region, which is usually provided with a collar of hairs. Historically, subtribal classification has been controversial, with subtribes Echinopsinae and Carlininae considered as either subtribes or as independent tribes (Cassini, 1819; Bentham, 1873; Hoffmann, 1894; Wagenitz, 1976). Several molecular studies have recognized Cardueae as monophyletic (Susanna et al., 1995; Garcia-Jacas et al., 2002; Susanna et al., 2006). In the most complete study to date, Susanna et al. (2006) identified four monophyletic lineages or subtribes within Cardueae: Cardopatiinae, Carlininae, Echinopsinae and the Carduinae-Centaureinae complex, rendering the Carduinae as paraphyletic. However, this study failed to solve basal relationships between these lineages. 
The main area of distribution of Cardueae is the Mediterranean region, with centers of endemism in the eastern and western Mediterranean, the western Irano-Turanian region, and North Africa (Susanna and Garcia-Jacas, 2007). The eastern limits of many genera are located in central Asia, in the mountains of Tian Shan, Pamir, and the Himalayas. A few genera occur in regions that are distant from these two areas (Mediterranean and Himalayas), for example, in Japan (Atractylodes DC., Cirsium Mill., Synurus Iljin), North America (Cirsium, Plectocephalus D. Don, and Saussurea DC.), South America (Centaurodendron Johow), and Australia (Rhaponticum Vaill.). Some genera are subcosmopolitan (Arctium L., Cirsium), whereas others include noxious weeds [Carthamus L., Centaurea L., Crupina (Pers.) DC., Notobasis Cass., Rhaponticum; Susanna and Garcia-Jacas, 2007]. There are also some striking intercontinental disjunctions. One example is Plectocephalus (Centaureinae), a genus distributed in East Africa, North America, and South America. A recent study (Susanna et al., 2011) suggests an origin of this lineage in West Asia with subsequent migrations to North America through the Bering Land Bridge. However, the scope of this study was restricted to subtribe Centaureinae, and its biogeographic conclusions were based exclusively on geological evidence. Here, we provide improved sampling and test these hypotheses within a formal biogeographic analysis based on fossil-calibrated molecular dating and ancestral area reconstructions. Other interesting disjunctions in Cardueae are shown by Rhaponticum, distributed in North Africa, Eurasia, Asia, and eastern Australia; and Cirsium, distributed in Eurasia, northern and eastern Africa, and North America.

Despite the importance of thistles for understanding the evolution of the Mediterranean vegetation and landscape (Quézel, 1978), there has been no attempt to infer the biogeographical history of this tribe. One reason for this is the absence of fossil record to estimate absolute divergence times. Another reason lies in the difficulty of resolving basal relationships among the different subtribes of Cardueae, since a sound phylogenetic hypothesis is a basic prerequisite for inferring biogeographic history. The recent discovery of new fossil evidence assigned to basal subfamilies (such as Barnadesioideae) within Compositae (Barreda et al., 2010a, b), together with advances in integrating phylogenetic uncertainty into biogeographic reconstructions (Nylander et al., 2008), has provided us with new and powerful tools to infer the spatiotemporal evolution of thistles.

The particular aims of our study are (1) to provide a resolved generic phylogeny of tribe Cardueae, with special focus on phylogenetic relationships among subtribes and major lineages, (2) to estimate divergence times for the main diversification events within Cardueae, (3) to infer the ancestral areas and main migration events within the tribe allowing us to explain how it attained such a widespread and disjunct distribution, and (4) to provide new insights into the evolution of the Mediterranean flora, of which tribe Cardueae is an important element (Quézel, 1978).

\section{MATERIALS AND METHODS}

Plant material-To facilitate the resolution of relationships at the subtribal level, we included members of all subtribes and informal groups described by Susanna et al. (2006) for tribe Cardueae in our sampling (Table 1). Species were also selected to maximize geographic representation, i.e., to include all the areas of distribution of the tribe. The final data set was based on Susanna et al (2006), to which we have added 10 additional species from seven different genera: Ancathia DC., Centaurodendron, Dipterocome Fisch. \& C. A. Mey., Goniocaulon Cass., Ochrocephala Dittrich, Plectocephalus, and Xanthopappus C.Winkl. (Table 1). In all, 132 species were included, with 62 of the 73 recognized genera in tribe Cardueae (Susanna and Garcia-Jacas, 2009) represented. Eight species representing additional tribes and subfamilies within Compositae, as well as related families were used as different alternative outgroups for the phylogenetic, dating, and biogeographical analyses (see below) based on Funk et al. (2009).

A total of 300 new sequences were generated for this study, and 359 sequences were downloaded from GenBank. Species names, voucher information, and GenBank accession numbers for all sequences are provided in Appendix S1 (see Supplemental Data in the online version of this article).

DNA extraction, amplification, and sequencing-DNA was extracted using the CTAB procedure (Doyle and Dickson, 1987) as modified by Soltis et al. (1991) and Cullings (1992) using fresh plant tissue from collections growing in the Botanical Institute of Barcelona, as well as silica-gel-dried leaves or herbarium specimens.

The ITS, $\operatorname{trn} L$-trnF region including the $\operatorname{trn} L$ intron, the $3^{\prime} \operatorname{trn} L$ (UAA) exon, and the intergenic spacer between $\operatorname{trnL}$ (UAA) and $\operatorname{trn} F$ (GAA), and the first 1000 base pairs at the $5^{\prime}$ end of the matK gene were amplified and sequenced following Susanna et al. (2006). The cpDNA $n d h F$ gene was amplified only in its $3^{\prime}$ region because of the low variation of the $5^{\prime}$ end of the gene (Kim and Jansen, 1995). We used a set of two primer pairs to obtain overlapping sequence fragments of the $3^{\prime}$ region of the $n d h F$ gene. For the $5^{\prime}$ fragment, we used $3^{\prime} \mathrm{F}$ as the forward primer (Eldenäs et al., 1999) and 1783R (1) as the reverse primer, and for the $3^{\prime}$ fragment, we used $1626 \mathrm{~F}$ (2) as the forward primer and +607 (Kim and Jansen, 1995) as the reverse primer. Both internal primers were specially designed for this study: (1) 1783R: 5'-ATT CAT ACC AAT CTA TTG AAT TGT-3' and (2) 1626F: 5'-TGA ATC GGA TAA TAC TAT GTT ATT-3'. The profile used for amplification consisted of $3 \mathrm{~min}$ at $94^{\circ} \mathrm{C}$, $1 \mathrm{~min}$ at $46^{\circ} \mathrm{C}, 1 \mathrm{~min} 20 \mathrm{~s}$ at $71^{\circ} \mathrm{C}$; followed by 34 cycles of $1 \mathrm{~min}$ at $94^{\circ} \mathrm{C}, 1 \mathrm{~min}$ at $50^{\circ} \mathrm{C}$, and $1 \mathrm{~min} 20 \mathrm{~s}$ at $71^{\circ} \mathrm{C}$; with an extension phase of $7 \mathrm{~min}$ at $71^{\circ} \mathrm{C}$. The cpDNA $r b c L$ gene was amplified in two overlapping fragments using the primer pairs 1F/724R (Olmstead et al., 1992) and 636F/1460R (Fay et al., 1998). The profile used for PCR amplification was as described by Roquet et al. (2009). All reactions were performed in $25 \mu \mathrm{L}$ volumes with $10 \% 10 \times$ AmpliTaq buffer, $10 \% 25 \mathrm{mmol} / \mathrm{L} \mathrm{MgCl}_{2}, 10 \%$ of $2 \mathrm{mmol} / \mathrm{L}$ dNTPs mix, $4 \%$ of each primer at $5 \mu \mathrm{mol} / \mathrm{L}, 0.5 \mu \mathrm{L}$ dimethyl sulfoxide (DMSO; Sigma-Aldrich, St. Louis, Missouri, USA), 1 U AmpliTaq DNA polymerase (Applied Biosystems, Foster City, California, USA) and $2 \mu \mathrm{L}$ of template DNA of an unknown concentration. In the amplifications of chloroplast regions, $2.5 \mu \mathrm{L}$ of $400 \mathrm{ng} / \mu \mathrm{L}$ BSA (New England Biolabs, Ipswich, Massachusetts, USA) were added to the reaction mixture, which was made up to $25 \mu \mathrm{L}$ with distilled, sterile water. PCR products were purified with ExoSAP-IT (USB Corp., Cleveland, Ohio, USA), and the amplified DNA segments were sequenced using BigDye Terminator Cycle Sequencing v.3.1 (Applied Biosystems) and the manufacturer's protocol at the University of Florida ICBR Core Facility on an ABI 3730xl capillary sequencer (Applied Biosystems).

Phylogenetic analyses-Sequences were edited using the program BioEdit 7.0.9.0 (Hall, 1999), aligned using the software T-Coffee (Notredame et al., 2000) and adjusted manually. T-Coffee is especially appropriate for difficult alignments because it uses a position-specific scoring scheme instead of a substitution matrix and has the ability to consider information from all sequences during each alignment step, not just those being aligned at a particular stage.

We used two data sets for the analyses. Data set 1 included sequences of nrDNA (ITS) and cpDNA (trnL-trnF, matK, $n d h F, r b c L)$ regions for 127 taxa and was used to resolve phylogenetic relationships within tribe Cardueae. Representatives of two other tribes from Carduoideae, Brachylaena discolor and Oldenburgia intermedia (tribe Oldenburgieae), and Tarchonanthus camphoratus (tribe Tarchonantheae), were used as outgroups for this data set. A second, larger data set of 132 taxa (data set 2) based only on the cpDNA regions (trnL-trnF, $m a t K, n d h F, r b c L)$ was used for the dating and biogeographical analyses. The ITS marker was excluded from this data set because of difficulties to align the most external outgroups (see below) and to avoid artifacts from simultaneously analyzing chloroplast and nuclear genomes, which have very different divergence rates (Wolfe et al., 1987). The cpDNA data set allowed us to include representatives of two subfamilies of Compositae that occur in the fossil record and might facilitate the provision of external calibration points for the dating analysis: Barnadesioideae, which is the sister subfamily of the remaining Compositae (Funk et al., 2009), represented here by Dasyphyllum leptacanthum and Chuquiraga spinosa; and Gochnatioideae, which is closely related to 
TABLE 1. Area coding for distribution areas as used in the Bayes-DIVA reconstruction of the biogeographic history of tribe Cardueae and allies is represented by letters (A, western Mediterranean Basin; B, eastern Mediterranean Basin (the Balkans Peninsula); C, Western Asia, including the Anatolian Peninsula, the Caucasus, the Levant region, Iran and Iraq; D, Central and North Europe; E, Middle Asia, including the Mountains of Tian Shan and Pamir; F, Japan; G, Macaronesia; H, North America; I, southern South America; J, Central and South Africa; K, Himalayan range; L, North Africa; M, coastal areas along the Indian Ocean from the Horn of Africa to India; and N, Australia). Informal groups used as in Susanna and Garcia-Jacas (2009).

\begin{tabular}{|c|c|c|c|}
\hline Taxon & Subgenus or informal group & Tribe or Subtribe & Distribution \\
\hline \multicolumn{4}{|l|}{ Outgroups } \\
\hline Boopis anthemoides Juss. & & Calyceraceae R.Br. ex Rich. & I \\
\hline Scaevola aemula R. Br. & & Goodeniaceae R. Brown & $\mathrm{N}$ \\
\hline \multicolumn{4}{|l|}{ Compositae } \\
\hline Brachylaena discolor DC. & & Oldenburgieae S. Ortiz & $\mathrm{J}, \mathrm{M}$ \\
\hline Oldenburgia intermedia Bond & & Oldenburgieae & $\mathrm{J}$ \\
\hline Chuquiraga spinosa D. Don & & Barnadesioideae K. Bremer \& R. K. Jansen & I \\
\hline Dasyphyllum leptacanthum (Gardner) Cabrera & & Barnadesioideae & I \\
\hline Gochnatia hiriartiana Medrano, Villaseñor \& Medina & & Gochnatioideae Panero \& V. A.Funk & I \\
\hline Tarchonanthus camphoratus L. & & Tarchonantheae Kostel. & $\mathrm{J}, \mathrm{M}$ \\
\hline \multicolumn{4}{|l|}{ Cardueae Cass. (Carduoideae Cass. ex Sweet, Compositae) } \\
\hline Cardopatium corymbosum (L.) Pers. & & Cardopatiinae Less. & $\mathrm{B}, \mathrm{C}, \mathrm{L}$ \\
\hline Cousiniopsis atractyloides (C. Winkl.) Nevski & & Cardopatiinae & $\mathrm{E}$ \\
\hline Atractylis cancellata $\mathrm{L}$. & & Carlininae Dumort. & $\mathrm{A}, \mathrm{B}, \mathrm{C}, \mathrm{L}$ \\
\hline Atractylis carduus (Forssk.) Christ. & & Carlininae & $\mathrm{C}, \mathrm{L}$ \\
\hline Atractylodes japonica Koidz. ex Kitam. & & Carlininae & $\mathrm{E}$ \\
\hline Carlina acanthifolia All. & & Carlininae & A, B, D \\
\hline Carlina falcata Svent. & & Carlininae & $\mathrm{G}$ \\
\hline Carlina gummifera $($ L.) Less. & & Carlininae & $\mathrm{A}, \mathrm{B}, \mathrm{L}$ \\
\hline Carlina lanata $\mathrm{L}$. & & Carlininae & $\mathrm{A}, \mathrm{B}, \mathrm{C}, \mathrm{L}$ \\
\hline Carlina vulgaris $\mathrm{L}$. & & Carlininae & $\mathrm{A}, \mathrm{B}, \mathrm{C}, \mathrm{D}$ \\
\hline Tugarinovia mongolica Iljin & & Carlininae & E \\
\hline Echinops acantholepis Jaub. \& Spach & & Echinopsinae (Cass.) Dumort. & $\mathrm{C}$ \\
\hline Echinops angustilobus S. Moore & & Echinopsinae & $\mathrm{J}, \mathrm{M}$ \\
\hline Echinops hoehnelii Schweinf. & & Echinopsinae & $\mathrm{J}, \mathrm{M}$ \\
\hline Echinops niveus Wall. & & Echinopsinae & $\mathrm{K}$ \\
\hline Echinops persicus Stev. \& Fisch. & & Echinopsinae & $\mathrm{C}$ \\
\hline Echinops tschimganicus B. Fedtsch. & & Echinopsinae & $\mathrm{E}$ \\
\hline Echinops viscosus DC. & & Echinopsinae & $\mathrm{B}, \mathrm{C}, \mathrm{L}$ \\
\hline Arctium eriophorum (Regel \& Schmalh.) Kuntze & Arctium-Cousinia group & Carduinae (Cass.) Dumort & $\mathrm{E}$ \\
\hline $\begin{array}{l}\text { Arctium grandifolium (Kult.) S. López, Romaschenko, } \\
\text { Susanna \& N. Garcia }\end{array}$ & Arctium-Cousinia group & Carduinae & $\mathrm{E}$ \\
\hline Arctium lappa $\mathrm{L}$. & Arctium-Cousinia group & Carduinae & $\mathrm{A}, \mathrm{B}, \mathrm{C}, \mathrm{D}, \mathrm{E}$ \\
\hline Arctium lappaceum (Schrenk) Kuntze & Arctium-Cousinia group & Carduinae & $\mathrm{E}$ \\
\hline Arctium minus Bernh. & Arctium-Cousinia group & Carduinae & $\mathrm{A}, \mathrm{B}, \mathrm{C}, \mathrm{D}$ \\
\hline Arctium triflorum (Schrenk) Kuntze & Arctium-Cousinia group & Carduinae & $\mathrm{E}$ \\
\hline Arctium umbrosum (Bunge) Kuntze & Arctium-Cousinia group & Carduinae & $\mathrm{E}$ \\
\hline Cousinia coronata Franch. & Arctium-Cousinia group & Carduinae & $\mathrm{E}$ \\
\hline Cousinia microcarpa Boiss. & Arctium-Cousinia group & Carduinae & $\mathrm{E}$ \\
\hline Cousinia polycephala Rupr. & Arctium-Cousinia group & Carduinae & $\mathrm{E}$ \\
\hline Berardia subacaulis Vill. & Berardia and Staehelina & Carduinae & $\mathrm{D}$ \\
\hline Staehelina dubia L. & Berardia and Staehelina & Carduinae & $\mathrm{A}, \mathrm{L}$ \\
\hline Staehelina fruticosa $\mathrm{L}$. & Berardia and Staehelina & Carduinae & $\mathrm{B}$ \\
\hline Staehelina lobelii DC. & Berardia and Staehelina & Carduinae & $\mathrm{B}, \mathrm{C}$ \\
\hline Carduus carlinoides Gouan & Carduus-Cirsium group & Carduinae & A \\
\hline Carduus defloratus $\mathrm{L}$. & Carduus-Cirsium group & Carduinae & A, D \\
\hline Carduus keniensis R. E. Fr. & Carduus-Cirsium group & Carduinae & $\mathrm{J}$ \\
\hline Carduus nyassanus R. E. Fr. & Carduus-Cirsium group & Carduinae & $\mathrm{J}, \mathrm{M}$ \\
\hline Cirsium echinus (M. Bieb.) Hand.-Mazz. & Carduus-Cirsium group & Carduinae & $\mathrm{C}$ \\
\hline Cirsium nipponicum Makino & Carduus-Cirsium group & Carduinae & $\mathrm{F}$ \\
\hline Cirsium ochrolepidium Juz. & Carduus-Cirsium group & Carduinae & $\mathrm{E}$ \\
\hline Cirsium palustre (L.) Scop. & Carduus-Cirsium group & Carduinae & $\mathrm{A}, \mathrm{B}, \mathrm{C}, \mathrm{D}$ \\
\hline Cirsium scariosum Nutt. & Carduus-Cirsium group & Carduinae & $\mathrm{H}$ \\
\hline Cirsium tanakae Matsum. & Carduus-Cirsium group & Carduinae & $\mathrm{F}$ \\
\hline Cirsium tracyi Rydb. & Carduus-Cirsium group & Carduinae & $\mathrm{H}$ \\
\hline Galactites tomentosa Moench & Carduus-Cirsium group & Carduinae & $\mathrm{A}, \mathrm{B}, \mathrm{L}$ \\
\hline Notobasis syriaca (L.) Cass. & Carduus-Cirsium group & Carduinae & $\mathrm{A}, \mathrm{B}, \mathrm{C}, \mathrm{L}$ \\
\hline Picnomon acarna (L.) Cass. & Carduus-Cirsium group & Carduinae & $\mathrm{A}, \mathrm{B}, \mathrm{C}, \mathrm{D}, \mathrm{L}$ \\
\hline Silybum marianum (L.) Gaertner & Carduus-Cirsium group & Carduinae & $\mathrm{A}, \mathrm{B}, \mathrm{C}, \mathrm{L}$ \\
\hline Tyrimnus leucographus (L.) Cass. & Carduus-Cirsium group & Carduinae & $\mathrm{A}, \mathrm{B}, \mathrm{C}, \mathrm{L}$ \\
\hline Cynara cornigera Lind. & Cynara group & Carduinae & $\mathrm{B}$ \\
\hline Cynara humilis L. & Cynara group & Carduinae & A, L \\
\hline Lamyropsis carpini Greuter & Cynara group & Carduinae & $\mathrm{B}$ \\
\hline Lamyropsis cynaroides (Lam.) Dittrich & Cynara group & Carduinae & $\mathrm{B}$ \\
\hline Ptilostemon abylensis (Maire) Greuter & Cynara group & Carduinae & $\mathrm{L}$ \\
\hline
\end{tabular}


TABle 1. Continued.

\begin{tabular}{|c|c|c|c|}
\hline Taxon & Subgenus or informal group & Tribe or Subtribe & Distribution \\
\hline Ptilostemon afer (Jacq.) Greuter & Cynara group & Carduinae & $\mathrm{B}, \mathrm{C}$ \\
\hline Ptilostemon diacanthus (Labill.) Greuter & Cynara group & Carduinae & $\mathrm{C}$ \\
\hline Ptilostemon hispanicus (Lam.) Greuter & Cynara group & Carduinae & A \\
\hline Jurinea albicaulis Bunge & Jurinea-Saussurea group & Carduinae & $\mathrm{E}$ \\
\hline Jurinea carduiformis Boiss. & Jurinea-Saussurea group & Carduinae & $\mathrm{C}$ \\
\hline Jurinea humilis DC. & Jurinea-Saussurea group & Carduinae & A, L \\
\hline Saussurea alpina (L.) DC. & Jurinea-Saussurea group & Carduinae & $\mathrm{D}, \mathrm{E}$ \\
\hline Saussurea discolor (Willd.) DC. & Jurinea-Saussurea group & Carduinae & $\mathrm{D}$ \\
\hline Alfredia cernua (L.) Cass. & Onopordum group & Carduinae & $\mathrm{E}$ \\
\hline Alfredia nivea Kar. \& Kir. & Onopordum group & Carduinae & $\mathrm{E}$ \\
\hline Ancathia igniaria (Spreng) DC. & Onopordum group & Carduinae & $\mathrm{E}$ \\
\hline $\begin{array}{l}\text { Lamyropappus schacaptaricus (B. Fedtsch.) } \\
\text { Knorr. \& Tamamsch. }\end{array}$ & Onopordum group & Carduinae & $\mathrm{E}$ \\
\hline Olgaea baldshuanica (C. Wink1.) Iljin & Onopordum group & Carduinae & $\mathrm{E}$ \\
\hline Olgaea pectinata Iljin & Onopordum group & Carduinae & $\mathrm{E}$ \\
\hline Onopordum nervosum Boiss. & Onopordum group & Carduinae & A \\
\hline Onopordum tauricum Willd. & Onopordum group & Carduinae & $\mathrm{B}, \mathrm{C}$ \\
\hline Synurus palmatopinnatifidus (Makino) Kitam. & Onopordum group & Carduinae & $\mathrm{F}$ \\
\hline Syreitschikovia spinulosa (Franch.) Pavlov & Onopordum group & Carduinae & $\mathrm{E}$ \\
\hline Xanthopappus subacaulis C. Winkl. & Onopordum group & Carduinae & $\mathrm{K}$ \\
\hline Amphoricarpos autariatus Blecic \& Mayer & Xeranthemum group & Carduinae & $\mathrm{B}$ \\
\hline Amphoricarpos exsul O. Schwarz & Xeranthemum group & Carduinae & $\mathrm{C}$ \\
\hline Dipterocome pusilla Fisch. \& C. A. Mey. & Xeranthemum group & Carduinae & $\mathrm{C}$ \\
\hline Chardinia orientalis (L.) O. Kuntze & Xeranthemum group & Carduinae & $\mathrm{C}$ \\
\hline Siebera pungens (Lam.) DC. & Xeranthemum group & Carduinae & $\mathrm{C}$ \\
\hline Xeranthemum annuиm L. & Xeranthemum group & Carduinae & $\mathrm{B}, \mathrm{C}, \mathrm{D}, \mathrm{E}$ \\
\hline Xeranthemum inapertum (L.) Miller & Xeranthemum group & Carduinae & A, B, C, L \\
\hline Xeranthemum longepapposum Fisch. \& C. A. Mey. & Xeranthemum group & Carduinae & $\mathrm{C}, \mathrm{E}$ \\
\hline Carduncellus duvauxii Batt. \& Trab. & Carthamus-Carduncellus group & Centaureinae (Cass.) Dumort & $\mathrm{L}$ \\
\hline Carthamus oxyacantha M. Bieb. & Carthamus-Carduncellus group & Centaureinae & $\mathrm{C}$ \\
\hline Carthamus turkestanicus Popov. & Carthamus-Carduncellus group & Centaureinae & $\mathrm{C}$ \\
\hline Femeniasia balearica (J. J. Rodr.) Susanna & Carthamus-Carduncellus group & Centaureinae & A \\
\hline Phonus rhiphaeus (Font Quer \& Pau) G. López & Carthamus-Carduncellus group & Centaureinae & $\mathrm{L}$ \\
\hline Klasea algida (Iljin) Hidalgo & Klasea group & Centaureinae & $\mathrm{E}$ \\
\hline Klasea coriacea (Fisch. \& C. A. Mey. ex DC.) Holub & Klasea group & Centaureinae & $\mathrm{C}$ \\
\hline Klasea serratuloides (DC.) Greuter \& Wagenitz & Klasea group & Centaureinae & $\mathrm{C}$ \\
\hline Serratula coronata $\mathrm{L}$. & Klasea group & Centaureinae & $\mathrm{D}, \mathrm{E}$ \\
\hline Centaurodendron palmiforme Skottsb. & Plectocephalus group & Centaureinae & I \\
\hline Plectocephalus americanus D. Don & Plectocephalus group & Centaureinae & $\mathrm{H}$ \\
\hline Plectocephalus chilensis G. Don ex Loudon & Plectocephalus group & Centaureinae & I \\
\hline $\begin{array}{l}\text { Plectocephalus tweediei (Hook. \& Arn.) } \\
\text { N. Garcia \& Susanna }\end{array}$ & Plectocephalus group & Centaureinae & I \\
\hline Plectocephalus varians (A. Rich.) C. Jeffrey & Plectocephalus group & Centaureinae & M \\
\hline Psephellus gilanicus (Bornm.) Wagenitz & Psephellus group & Centaureinae & $\mathrm{C}$ \\
\hline Psephellus persicus (DC.) Wagenitz & Psephellus group & Centaureinae & $\mathrm{C}$ \\
\hline Psephellus pulcherrimus (Willd.) Wagenitz & Psephellus group & Centaureinae & $\mathrm{C}$ \\
\hline Callicephalus nitens (M. Bieb. ex Willd.) C. A. Mey. & Rhaponticum group & Centaureinae & $\mathrm{C}, \mathrm{E}$ \\
\hline Centaurothamnus maximus Wagenitz \& Dittrich & Rhaponticum group & Centaureinae & $\mathrm{M}$ \\
\hline Myopordon aucheri Boiss. & Rhaponticum group & Centaureinae & $\mathrm{C}$ \\
\hline Myopordon hyrcanum (Bornm.) Wagenitz & Rhaponticum group & Centaureinae & $\mathrm{C}$ \\
\hline Ochrocephala imatongensis (Philipson) Dittrich & Rhaponticum group & Centaureinae & M \\
\hline Rhaponticum acaule DC. & Rhaponticum group & Centaureinae & $\mathrm{L}$ \\
\hline Rhaponticum australe (Gaud.) Soskov & Rhaponticum group & Centaureinae & $\mathrm{N}$ \\
\hline Rhaponticum repens (L.) Hidalgo & Rhaponticum group & Centaureinae & $\mathrm{B}, \mathrm{C}$ \\
\hline Mantisalca salmantica (L.) Briq. \& Cavill. & Volutaria group & Centaureinae & $\mathrm{A}, \mathrm{B}, \mathrm{C}, \mathrm{L}$ \\
\hline Goniocaulon indicum C. B. Clarke & Volutaria group & Centaureinae & $\mathrm{M}$ \\
\hline Volutaria crupinoides (Desf.) Maire & Volutaria group & Centaureinae & $\mathrm{C}, \mathrm{L}$ \\
\hline Schischkinia albispina (Bunge) Iljin & Volutaria group & Centaureinae & $\mathrm{E}$ \\
\hline Centaurea depressa M. Bieb. & Subg. Cyanus & Centaureinae & $\mathrm{C}$ \\
\hline Centaurea lingulata Lag. & Subg. Cyanus & Centaureinae & A \\
\hline Centaurea behen $\mathrm{L}$. & Subg. Centaurea & Centaureinae & $\mathrm{C}$ \\
\hline Centaurea bruguierana (DC.) Hand.-Mazz. & Subg. Centaurea & Centaureinae & $\mathrm{C}$ \\
\hline Centaurea involucrata Desf. & Subg. Centaurea & Centaureinae & $\mathrm{A}, \mathrm{L}$ \\
\hline Centaurea carolipauana Fern. Casas \& Susanna & Subg. Acrocentron & Centaureinae & $\mathrm{L}$ \\
\hline Centaurea lagascana Graells & Subg. Acrocentron & Centaureinae & A \\
\hline $\begin{array}{l}\text { Crocodilium creticum (Boiss. \& Heldr.) } \\
\text { N. Garcia \& Susanna }\end{array}$ & & Centaureinae & $\mathrm{C}$ \\
\hline Crocodilium syriacum Cass. & & Centaureinae & $\mathrm{C}$ \\
\hline Cheirolophus mauritanicus (Font Quer) Susanna & & Centaureinae & $\mathrm{L}$ \\
\hline
\end{tabular}


TABle 1. Continued.

\begin{tabular}{llc}
\hline \hline Taxon & Subgenus or informal group & Tribe or Subtribe \\
\hline Cheirolophus teydis (C. Smith) G. López & Centaureinae & Distribution \\
Rhaponticoides hajastana (Tzvel.) M. V. Agab. \& Greuter & Centaureinae & G \\
Stizolophus balsamita (Lam.) Cass. ex Takht. & Centaureinae & C \\
Stizolophus coronopifolius Cass. & Centaureinae & C \\
Zoegea leptaurea L. & Centaureinae & C \\
\hline
\end{tabular}

Carduoideae (Funk et al., 2009), represented by Gochnatia hiriartiana. Finally, a member of family Goodeniaceae (Scaevola aemula), and Boopis anthemoides, belonging to family Calyceraceae, were included as external outgroups because these two families have been shown to be closely related to Compositae (Lundberg, 2009), following the relationship: ((Calyceraceae, Compositae), Goodeniaceae).

We first performed a partition homogeneity test (incongruence length difference, ILD; Farris et al., 1995a, b) to test the heterogeneity of phylogenetic signals between the chloroplast and the nuclear markers on data set 1 . The ILD significance values were calculated in the program TNT v.1.1 (Goloboff et al., 2008) with the INCTST script (kindly provided by the authors of the program) using 1000 replicates. The ILD test indicated significant incongruence between the ITS and cpDNA data sets $(P=0.001)$. However, numerous studies have discussed the limitations in interpreting this test (e.g., Hipp et al., 2004; Quicke et al., 2007). We, therefore, performed additional separate phylogenetic analyses (same settings as below) for the ITS and the cpDNA markers and made direct comparisons between their consensus trees. In the resulting trees (Appendices S2 and S3, see online Supplemental Data), all clades receiving significant node support in the bootstrap (70\%) and Bayesian $(95 \%)$ analyses were congruent between nuclear and chloroplast markers, except for two groupings. First, the Arctium-Cousinia complex, which is resolved as sister to the Centaureinae together with the Jurinea-Saussurea clade in the ITS (Appendix S3). This result is caused by a 7-bp- deletion in the ITS shared by the Centaureinae and the Arctium-Cousinia and Jurinea-Saussurea clades (Häffner and Hellwig, 1999). The second one is the position of some annual Centaureinae genera (Goniocaulon, Stizolophus Cass., and Zoegea L.). As argued by Susanna et al. (2011), these annual genera are probably misplaced in the ITS phylogenetic tree due to a long-branch attraction artifact caused by the higher divergence rate. We, therefore, decided to combine all markers into a single concatenated data set for further phylogenetic analysis of data set 1: the position of the annual taxa in the combined tree agreed with that in the cpDNA data set.

We coded indels (gaps) as additional characters for the analyses of data set 1using the Modified Complex Indel Coding (MCIC) algorithm (Müller, 2006) implemented in the program IndelCoder 1.0 (Müller, 2006). Indels were excluded from data set 2 because of difficulties in estimating the rate of variation of the molecular clock in the gap partition.

Phylogenetic analyses of data sets 1 and 2 were performed using maximum parsimony (MP) and Bayesian inference (BI) methods, implemented in the programs PAUP* v.4.0b10 (Swofford, 2002) and MrBayes 3.2 (Ronquist and Huelsenbeck, 2003), respectively. MP analyses used heuristic search with 1000 replicates of random taxon addition with MULPARS in effect and tree-bisection-reconnection (TBR) branch swapping and saving all the most parsimonious trees. Parsimony uninformative positions were excluded. After the strict consensus tree was computed, bootstrap analyses (BS; Felsenstein, 1985) were performed following Lidén at al. (1997), using 1000 replicates of heuristic search, 10 random taxon additions with 10 replicates per replicate, MULTREES option not in effect, and no branch swapping. Nodes with BS $\geq 75 \%$ were considered as significantly supported.

The Akaike information criterion (Akaike, 1973), as implemented in the software MrModeltest 2.3 (Nylander, 2004), was used to select the best-fit model of substitution for each region for the BI analyses. The general time reversible model with variable sites was assumed to follow a gamma distribution, and an invariant portion $(\mathrm{GTR}+\mathrm{I}+\mathrm{G})$ was selected for all regions except for $m a t K(\mathrm{GTR}+\mathrm{G})$. However, several studies have shown that the invariable gamma parameter can overestimate the rate of molecular evolution and, consequently, affect the estimation of divergence times (Wahlberg, 2006). We, thus, decided to use GTR $+\mathrm{G}$ as model of evolution for all DNA regions. For the gap partition, we used the restriction model (F81) in accordance with the MrBayes manual (Table 2). Two independent analyses of three Metropolis-coupled Markov chains were run for 5 million generations in MrBayes, starting from different random trees and with the heating temperature parameter set to 0.1 , saving one in every 1000 trees. A 50\% majority rule consensus tree was computed from the posterior distribution after discarding the first $25 \%$ of trees as burn-in. Nodes with a Bayesian posterior probability (BPP) of between 0.5 and 0.74 were considered as weakly supported, $0.75 \geq \mathrm{BPP} \geq 0.89$ as moderately supported, and $0.9 \geq \mathrm{BPP} \geq 1$ as well supported.

Dating analyses-We used the nonparametric dating method implemented in the software PATHd8 (Britton et al., 2007) to estimate the percentage of nodes in the 50\% majority rule consensus tree from the Bayesian analysis of data set 2 that conformed to the expectations of a molecular clock. Because $87.80 \%$ of nodes did not follow a molecular clock, we used a relaxed-clock, semiparametric approach, penalized likelihood (PL; Sanderson, 2002), implemented in the program r8s v1.70 (Sanderson, 2003), to estimate divergence times within Cardueae. Penalized likelihood allows divergence rates to vary along the tree but penalizes rate variation between ancestor and descendant by a smoothing parameter. To select an optimal level of smoothing, we performed the fossil cross-validation process (Near and Sanderson, 2004). Phylogenetic uncertainty in divergence times was incorporated using a similar approach to Buerki et al. (2011): we performed PL analysis on 1000 trees randomly selected from the Bayesian Markov chain Monte Carlo (MCMC) stationary distribution,

TABLE 2. Numerical results from the phylogenetic analyses (MP) of the combined (nrDNA + cpDNA) data set and the chloroplast-only (cpDNA) data set. Models of nucleotide evolution for each independent marker used in the Bayesian inference analysis.

\begin{tabular}{|c|c|c|c|c|c|c|c|}
\hline Data set & ITS & $\operatorname{trnL}-\operatorname{trnF}$ & matK & $\mathrm{ndhF}$ & $r b c L$ & 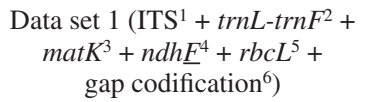 & $\begin{array}{c}\text { Data set } 2 \\
\left(\operatorname{trnL}-\operatorname{trn} F^{2}+m a t K^{3}+\right. \\
\left.n d h F^{4}+r b c L^{5}\right)\end{array}$ \\
\hline No. of taxa & - & - & - & - & - & 127 & 132 \\
\hline Length range (bp) & $594-647$ & $765-848$ & 282-991 & $1301-1316$ & $1416-1422$ & $3847-4591$ & $3847-4581$ \\
\hline Total characters & 685 & 947 & 1003 & 1328 & 1431 & 5617 & 4709 \\
\hline Variable characters (\%) & $439(64.09)$ & $236(24.92)$ & $352(35.09)$ & $322(24.25)$ & $200(13.98)$ & 1549 & 1110 \\
\hline $\begin{array}{l}\text { Parsimony informative } \\
\text { characters }\end{array}$ & 350 & 133 & 179 & 194 & 116 & 1080 & 622 \\
\hline No. of indels & 172 & 320 & 723 & 34 & 19 & 1268 & 1096 \\
\hline No. of steps & 2886 & 256 & 392 & 516 & & 4817 & 1925 \\
\hline Consistency index (CI) & 0.24 & 0.65 & 0.59 & 0.51 & & 0.33 & 0.5 \\
\hline Retention index (RI) & 0.65 & 0.86 & 0.83 & 0.83 & & 0.71 & 0.79 \\
\hline Homoplasy index (HI) & 0.76 & 0.34 & 0.41 & 0.49 & & 0.66 & 0.5 \\
\hline Model of evolution & & & & & & $\mathrm{GTR}+\mathrm{G}^{1,2,3,4,5}, \mathrm{~F} 81^{6}$ & $\mathrm{GTR}+\mathrm{G}^{2,3,4,5}$ \\
\hline
\end{tabular}


after discarding those trees that did not conform with the topological constraints imposed by the fossil calibrations, i.e., trees that did not support the monophyly of clades to which a fossil calibration point was attached (see below). Results from the 1000 dating analyses were summarized using the program TreeAnnotator v1.4.7 (Drummond and Rambaut, 2007) and subsequently used to estimate mean values and $95 \%$ confidence intervals for each node in the halfcompat consensus tree (Buerki et al., 2011).

Age constraints and the fossil record-Until recently, Asterales had a scant fossil record, and macrofossils were known mainly from the Neogene (Barreda et al., 2010b). New fossil discoveries in the last two years, however, have provided better estimates of the age of divergence of some basal lineages within Compositae, such as Barnadesioideae, as well as of closely related families such as Calyceraceae, Goodeniaceae, and Menyanthaceae. In particular, the pollen fossil record has been greatly enriched (see Barreda et al., 2010a, for a review).

Six fossil calibration points were used for estimating ages of divergence between lineages: (1) The earliest accepted pollen fossil record of Compositae is Tubulifloridites sp. from the Paleocene-Eocene boundary of South Africa (Zavada and De Villiers, 2000; Zavada and Lowrey, 2010; Barreda et al., 2010a). We have used this age as a fixed age of 55.8 Ma for the stem Compositae in the dating analyses. (2) The second calibration point used was the Raiguenrayun cura Barreda, Katinas, Passalia \& Palazzesi capitulescence from the Patagonian described as belonging to the crown Compositae (Barreda et al., 2012) and dated by radiometric methods at 47.5 Ma. We have used this fossil as a minimum age constraint for the split between Barnadesioideae and the rest of Compositae. (3) As a minimum age constraint for the crown group of the subfamily Barnadesioideae, we used the fossil pollen Quilembaypollis sp., from the Patagonian Oligocene-Miocene, dated at 23 Ma (Palazzesi et al., 2009). (4) Split of lineages Arctium minus and A. lappa was set to a minimum age of $8 \mathrm{Ma}$, based on mid-late Miocene achenes described by Mai (2001) and assigned to Arctium (López-Vinyallonga et al., 2009). (5) Stem lineage of Carduus-Cirsium was set to a minimum age of $14 \mathrm{Ma}$ based on mid Miocene achenes identified as Cirsium (Mai, 1995). (6) The minimum stem age for Centaurea was set to $5 \mathrm{Ma}$, based on several records of pollen and achenes for this genus dating from the early Pliocene onward (e.g., Mai, 1995; Popescu, 2002).

Ancestral area reconstruction-Biogeographic areas were defined on the basis of patterns of endemicity among current taxa (Table 2; Susanna and GarciaJacas, 2007; Greuter, 2006-2009) and to maximize congruence with large-scale biogeographic patterns and paleogeographic history (Takhtajan, 1986). Generic distributions were scored according to the distribution of the species representing each genus in the data set. These in turn were selected so as to cover the entire distribution range of the genus and to minimize bias in taxon sampling. Additionally, we checked phylogenetic studies on several genera of Cardueae (Hidalgo et al., 2006; Garnatje et al., 2007; Garcia-Jacas et al., 2008; LópezVinyallonga et al., 2009; Sánchez-Jiménez et al., 2010; Vilatersana et al., 2000, 2010) to ensure that the scored distribution ranges represent the most likely ancestral distribution of the genus (sensu Ronquist, 1996); for example, we discarded rare distributions that were presumably the result of human introductions (Nylander et al., 2008). Fourteen areas were defined (Fig. 1): A, western Mediterranean Basin; B, eastern Mediterranean Basin (the Balkans Peninsula); $\mathrm{C}$, western Asia, including the Anatolian Peninsula, the Caucasus, the Levant region, Iran and Iraq; D, Central and North Europe; E, Middle Asia, including the mountains of Tian Shan and Pamir; F, Japan; G, Macaronesia; H, North America; I, southern South America; J, Central and South Africa; K, Himalayan range; L, North Africa; M, coastal areas along the Indian Ocean from the Horn of Africa to India; and N, Australia.

A parsimony method that minimizes dispersal and extinction events, dispersal-vicariance analysis (DIVA, Ronquist, 1997), was used to reconstruct ancestral areas and biogeographic events for the main lineages within Cardueae based on data set 2 . We assumed that the dispersal ability of the ancestors was probably not higher than that of extant species (Sanmartín, 2003) and limited the maximum number of areas in ancestral distributions in DIVA to four, which is the maximum distributional range of most species within Cardueae. To account for uncertainty in phylogenetic relationships, i.e., the existence of soft polytomies and/or weak nodal support in the Bayesian majority-rule consensus tree, we followed the Bayes-DIVA approach of Nylander et al. (2008). We used Perl scripts (Nylander et al., 2008) to average DIVA parsimony-based reconstructions over a post burn-in sample of trees from the MCMC Bayesian analysis of data set 2 (in all 7502 trees). We then summarized these frequencies as marginal probabilities for alternative ancestral areas for each node in a reference tree, in this case, the halfcompat consensus tree of data set 2.

\section{RESULTS}

Table 2 shows sequence variation and several numeric parameters from the phylogenetic analysis of the combined (ITS + cpDNA) data set 1 and the chloroplast (cpDNA) data set 2. Both data sets recovered similar topologies under the two methods of phylogenetic inference (MP and BI). Figure 2 and online Appendix S2 show the BI consensus tree with bootstrap support (BS) and posterior probability (BPP) values for each node for data sets 1 and 2, respectively. Since the combined data set provided further resolution in the basal nodes and generally yielded better support values, we discuss here phylogenetic relationships based on data set 1 (Fig. 2).

Our phylogenetic analysis supported the monophyly of tribe Cardueae (BS $=100 \%$, BPP $=1$; Fig. 2) and of subtribes Cardopatiinae (BS = 99\%, BPP = 1; Fig. 2), Carlininae (BPP = 1; Fig. 2), Echinopsinae (BS $=100 \%, \mathrm{BPP}=1$; Fig. 2), and Centaureinae $(\mathrm{BS}=100 \%, \mathrm{BPP}=1$; Fig. 2), the latter embedded within Carduinae. Subtribe Cardopatiinae was shown as a sister group to the rest of subtribes, while subtribes Carlininae and Echinopsinae appeared as consecutive sister clades to the Carduinae/ Centaureinae clade (Fig. 2). The phylogenetic position of subtribe Echinopsinae was only moderately supported $(\mathrm{BPP}=0.84$; Fig. 2). Subtribe Carduinae was recovered as paraphyletic in the analysis, with Centaureinae nested within it (Fig. 2). Phylogenetic relationships within the main informal groups defined by Susanna et al. (2006) and Susanna and Garcia-Jacas (2009) were only partially resolved. Within subtribe Carduinae, the formerly unassigned genus Dipterocome was placed with the Xeranthemum group as sister to the rest of the taxa (BS $=79 \%, \mathrm{BPP}=1$; Fig. 2). The two African Carduus L. species in our analyses (C. keniensis and C. nyassanus) were here shown to be closely related to Cirsium, rendering Cirsium as paraphyletic (Fig. 2). The Arctium-Cousinia group was recovered as polyphyletic, with Cousinia Cass. nested within the Jurinea-Saussurea group (BPP = 1; Fig. 2). Within subtribe Centaureinae, a basal clade including Goniocaulon, Schischkinia Iljin and Volutaria Cass. (e.g., the Volutaria group; excluding Mantisalca salmantica) was shown as sister to the rest of the taxa (Fig. 2). Our analysis also confirmed the monophyly of "core" Centaureinae, with Rhaponticoides hajastana as sister to the rest of the clade, including Centaurea s.s. and the Carthamus-Carduncellus group (Fig. 2).

Phylogenetic analysis of data set 2 (Appendix S2) produced a tree topology with the same supported clades as data set 1 . The only exception was the clade grouping the Arctium-Cousinia group, the Carduus-Cirsium group and the Cynara group, which was recovered as sister group to Centaureinae, with a high BPP support value (BPP = 1; Appendix S2).

Figure 3 provides mean divergence times for all nodes within Cardueae and Appendix S4 (see Supplemental Data in the online version of this article) shows mean age values and credibility intervals. Figure 4 displays ancestral ranges of tribe Cardueae. According to our spatiotemporal reconstruction, tribe Cardueae originated around the Middle Eocene (Fig. 3) in West Asia (node 7, Fig. 4). The origin of Cardopatiinae diversification was dated in the Early Oligocene (Fig. 3), with considerable uncertainty in its biogeographic origin, although West Asia (area C) and Middle Asia (E) were included within the ancestral ranges with the highest marginal probability (node 2, Fig. 4). An ambiguous origin for subtribe Carlininae diversification in the Late Eocene was inferred (Fig. 3), but again West Asia-Middle Asia (areas C and E), formed part of the most likely ancestral range (node 3, Fig. 4). 


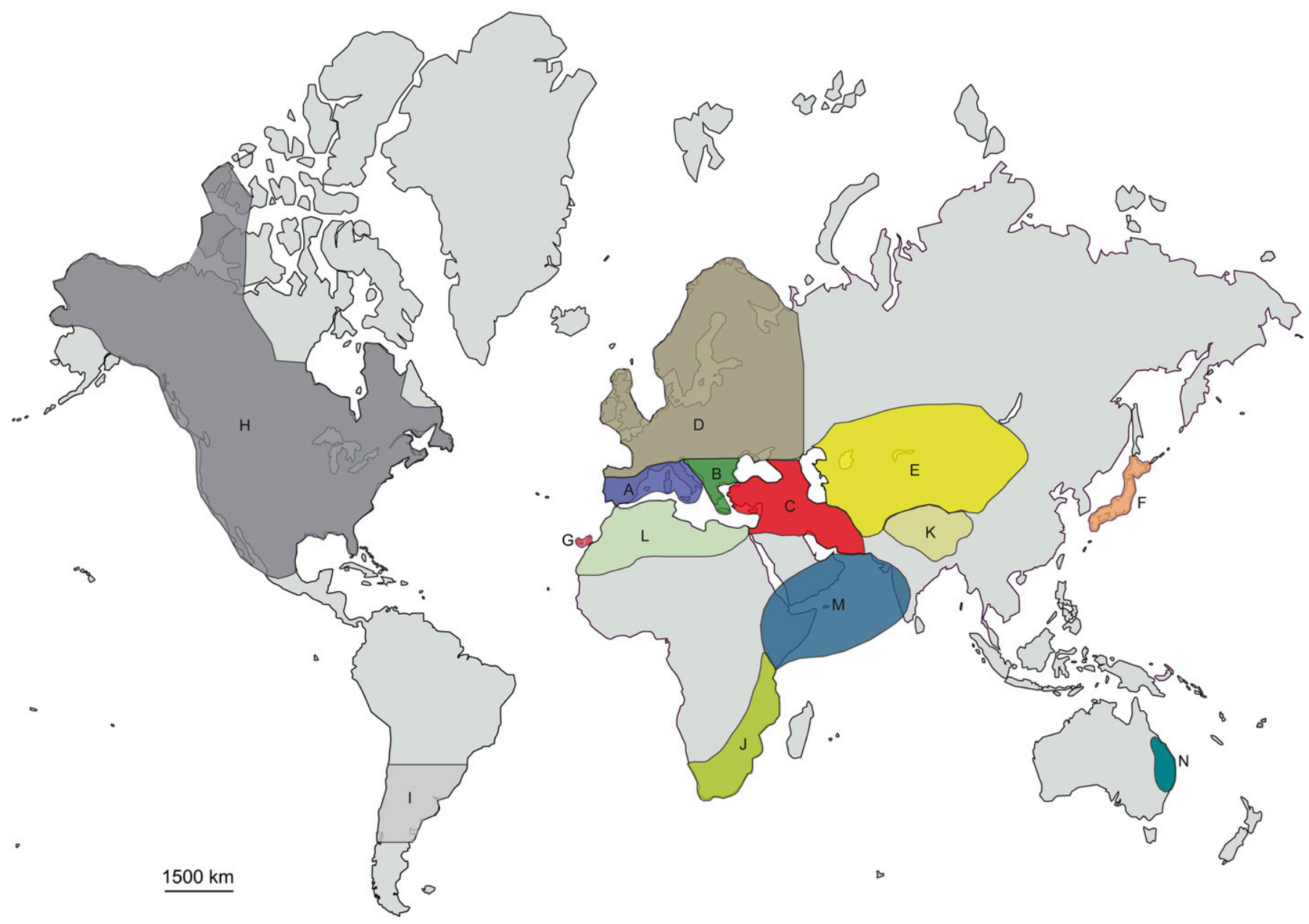

Fig. 1. The 14 distribution areas of tribe Cardueae and close relatives used in the Bayes-DIVA biogeographic reconstruction: A, western Mediterranean Basin; B, eastern Mediterranean Basin (the Balkans Peninsula); C, western Asia; D, Central and North Europe; E, Middle Asia; F, Japan; G, Macaronesia; H, North America; I, southern South America; J, Central and South Africa; K, Himalayan range; L, North Africa; M, coastal areas along the Indian Ocean from Horn of Africa to India and N, Australia.

Subtribes Echinopsinae, Carduinae, and Centaureinae were reconstructed to have radiated in West Asia (nodes 4-6; Fig. 4) during the Early Miocene, the Late Eocene, or the Late Oligocene, respectively (Fig. 3).

\section{DISCUSSION}

Phylogenetic relationships-In comparison with previous studies of the tribe (Susanna et al., 2006; Garcia-Jacas et al., 2002), our phylogeny, including two new cpDNA markers, provided better resolution of basal relationships within Cardueae. Cardopatiinae was reconstructed as sister group to the other subtribes, with subtribe Carlininae diverging next, followed by Echinopsinae, although the phylogenetic position of the latter was not well supported (Fig. 2, Appendix S2). Petit (1997) interprets similarities between the inflorescences of subtribes Cardopatiinae and Echinopsinae as indicating a close phylogenetic relationship, but our phylogeny indicated that these are probably the result of convergence, with Echinopsinae closer to the Carduinae-Centaureinae clade.
Our study showed Carlininae as the next diverging subtribe within Cardueae (Fig. 2, Appendix S2). This subtribe is characterized by some morphological traits, such as the presence of true ligules in Atractylis, that are considered to be plesiomorphic within Cardueae (Susanna and Garcia-Jacas, 2009). Within subtribe Carduinae, Dipterocome was shown as sister-group to the remaining genera of the Xeranthemum group (Fig. 2, Appendix S2), with which it shares (together with Siebera J. Gay) a bilabiate corolla (Anderberg et al., 2007). Our phylogenetic analysis did not agree with previous studies (LópezVinyallonga et al., 2009) on the phylogenetic relationships within the Arctium-Cousinia group, which could be due to different general sampling and outgroup selection of these two works, with different aims. Although previous studies (Vilatersana et al., 2010) found statistical support for the monophyly of the Cynara complex [including Cynara L., Lamyropsis (Kharadze) Dittrich, and Ptilostemon Cass.], this was not supported by our analyses (Fig. 2, Appendix S2). The position of the annual Mediterranean species Galactites tomentosa could not be resolved (Fig. 2, Appendix S2), and this can be explained by a longbranch attraction artifact produced by the rapid accumulation of 


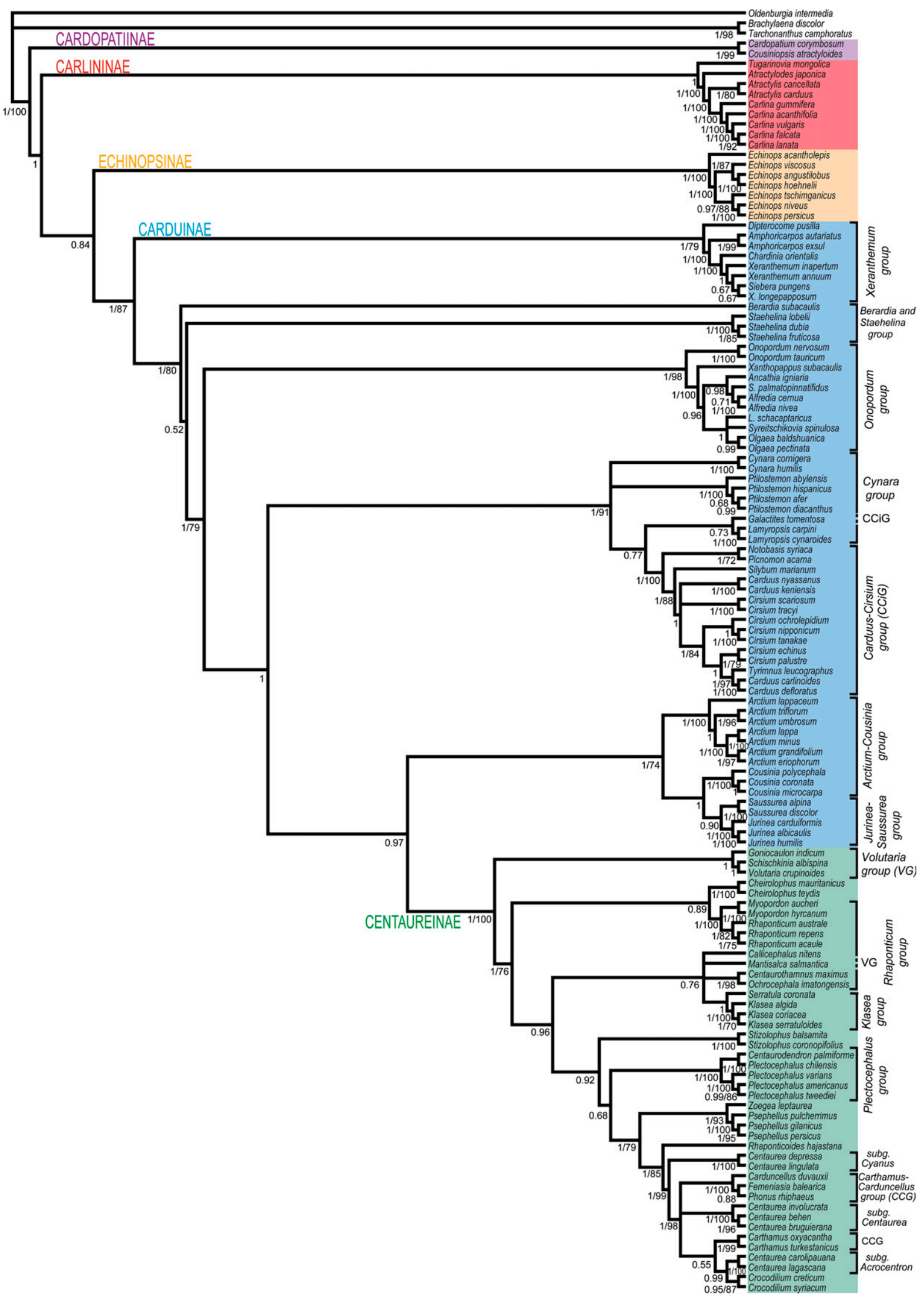

Fig. 2. Majority-rule ("halfcompat") consensus tree from a Bayesian analysis of the combined (nuclear and chloroplast) data set of tribe Cardueae (Compositae), with bootstrap values $(\geq 75 \%)$ and Bayesian posterior probabilities $(\geq 0.50)$ indicated below branches. 


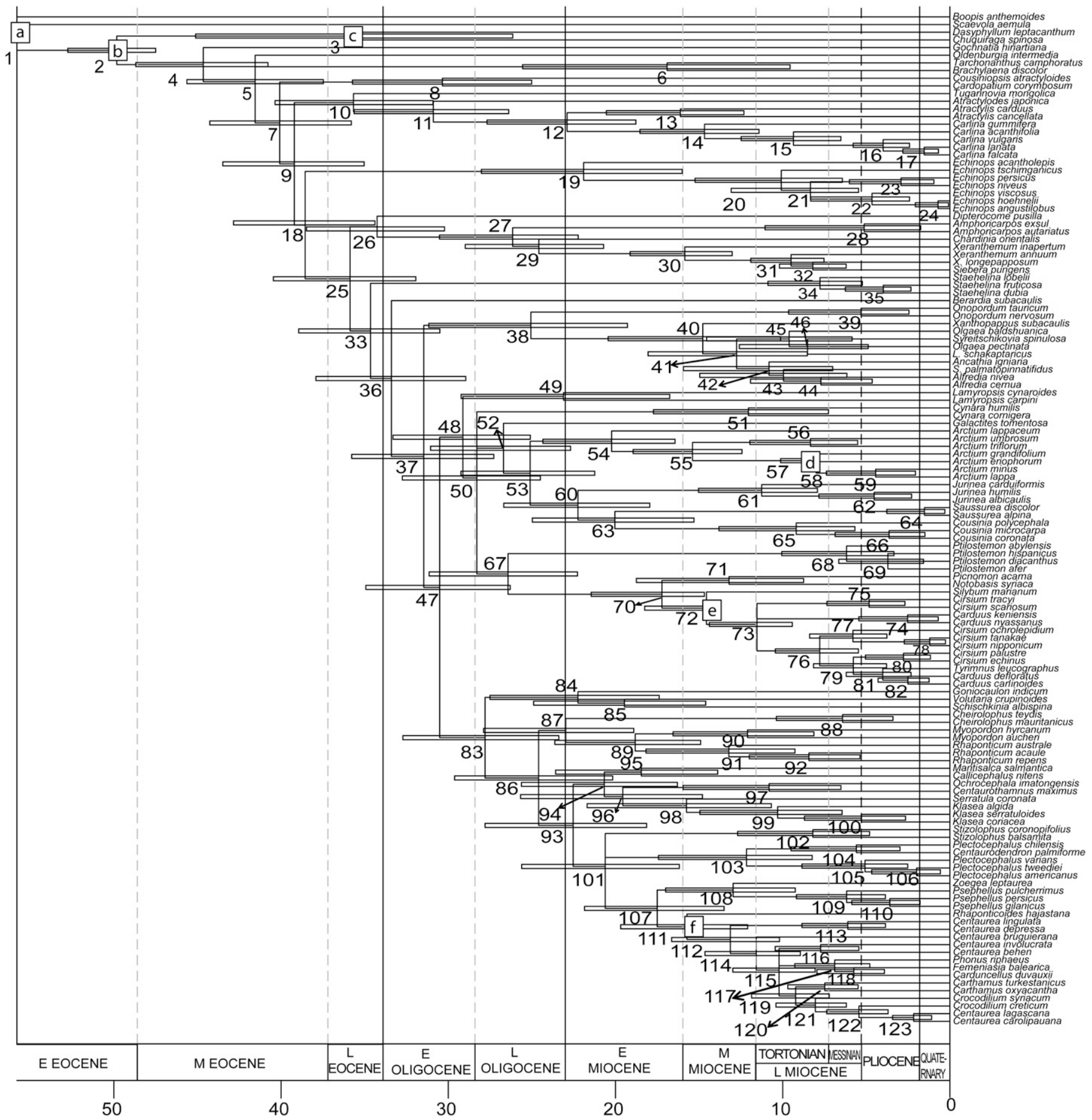

Fig. 3. Chronogram showing the majority-rule "halfcompat" consensus tree from the Bayesian analysis of the chloroplast data set of tribe Cardueae (Compositae) and close allies, with mean divergence times and confidence intervals (95\%) for nodal ages estimated by penalized likelihood (PL) over a sample of 1000 trees from the Markov chain Monte Carlo stationary distribution of this analysis. Lowercase letters in box indicate the nodes calibrated with fossil constraints. Node numbers refer to online Appendix S4.

evolutionary changes resulting from the annual life cycle of this species (Felsenstein, 1978). Taxonomic delimitation of the two largest genera Carduus (90 species) and Cirsium (250 species) has long been controversial (Häffner and Hellwig, 1999). Our analyses confirmed the close relationship among Carduus species from tropical East Africa and Cirsium (Fig. 2, Appendix S2).
Häffner and Hellwig (1999) suggest the same affinities on the basis of morphological similarities.

Within subtribe Centaureinae, the Volutaria group (Fig. 2, Appendix S2) was placed as sister group to the rest of Centaureinae, in agreement with Susanna et al. (2011). The annual genus Schischkinia was nested within this clade. Previous phylogenetic studies 


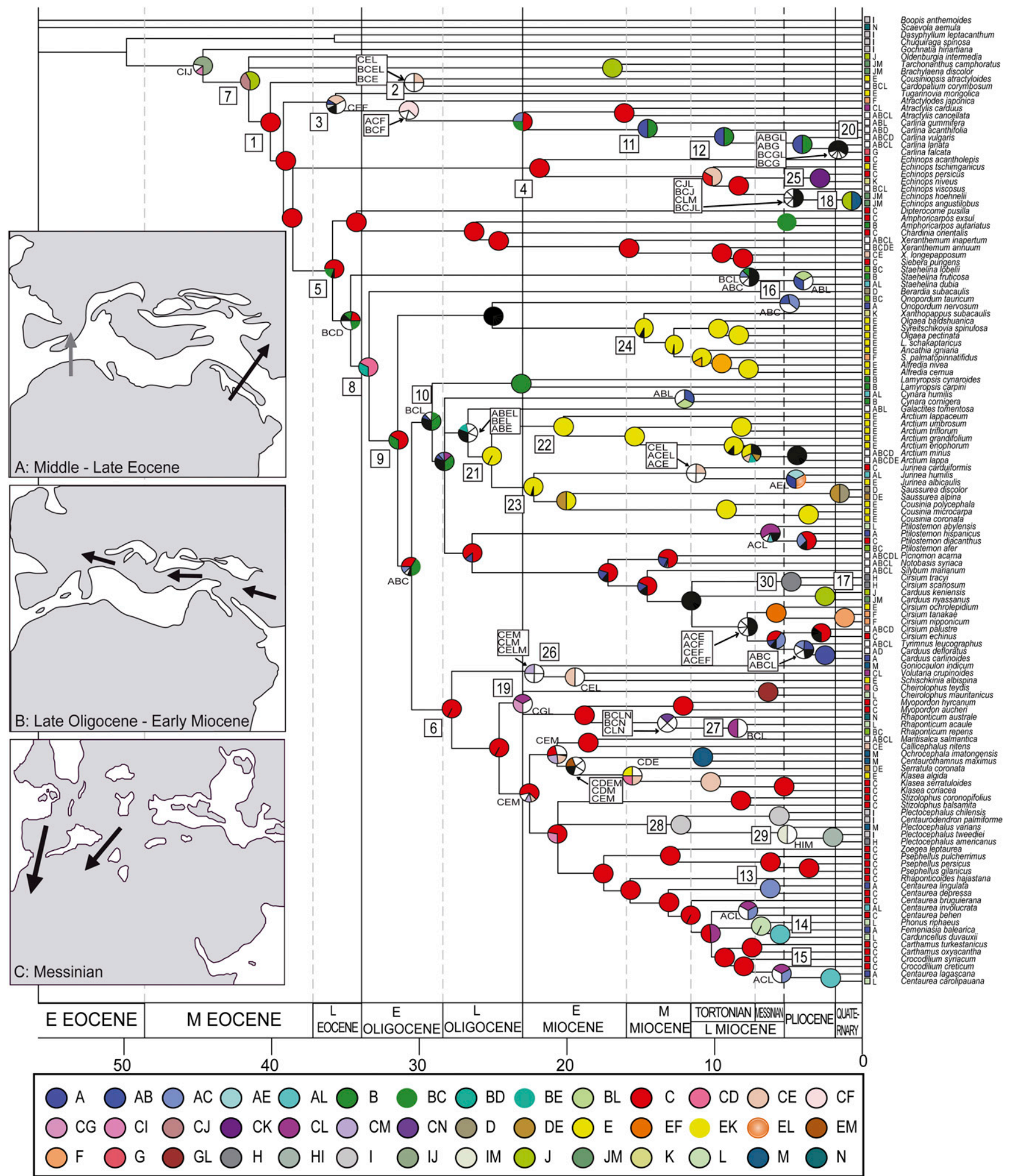

Fig. 4. Bayesian dispersal-vicariance (Bayes-DIVA) reconstruction of the biogeographic history of tribe Cardueae (Compositae) and close allies plotted on the penalized likelihood (PL) chronogram of Fig. 3. Distribution areas that are given before each taxon name and next to the pie chart legend are defined in Fig. 1. The pie charts represent the marginal probabilities of ancestral areas reconstructed for each node in Fig. 3, as estimated by averaging DIVA reconstructions over a Markov chain Monte Carlo stationary distribution from the Bayesian analysis of the chloroplast data set. Color codes for ancestral areas are shown in the inset, with ancestral area probabilities $<0.1$ pooled together (summed) into the black section of the pie chart. Ancestral area reconstructions assigned to more than four areas together are shown in white and labeled. Numbers close to the nodes indicate nodes discussed in the text. Maps showing paleogeographical reconstructions of the Mediterranean area since the Eocene are redrawn after Ree and Sanmartín (2009) and Santos-Gally et al. (2011). 
(Garcia-Jacas et al., 2001; Susanna et al., 2006) group Schischkinia within a clade of annual genera, including Stizolophus and Zoegea, but this position is likely to be an artifact derived from the inclusion of annuals within a group of mainly perennial genera. LópezVinyallonga et al. (2009) already discussed other examples of artificial placement of annual species nested within mainly perennial lineages within Cardueae. As in Susanna et al. (2011) the American Plectocephalus was monophyletic only if it included Centaurodendron, the pachycaul tree endemic to Juan Fernández Islands. Further discussion on this clustering is reported in Susanna et al. (2011). Rhaponticoides Vaill. has been related to several basally diverging groups in Centaureinae based on the presence of morphological traits, such as a caudate hilum, the Centaurea centaurium-pollen type, and a chromosome number of $x=15$ (Garcia-Jacas et al., 1996). However, our analyses showed that this species is more closely related to other "core" Centaureinae genera (Fig. 2).

Historical biogeography of Cardueae-Divergence among the three tribes of Carduoideae included in this study (Cardueae, Oldenburgieae, and Tarchonantheae) was dated to approximately the Middle Eocene. Despite this early divergence, only Cardueae presents a high species diversity and a range of distribution out of Africa. The aridification process that began in Africa from the Oligocene onwards (Ortiz et al., 2009) could explain the low radiation in the other tribes, which remained restricted to this area.

Within Cardueae, our dating biogeographic analysis suggested a complex biogeographical history, with an origin in West Asia and early diversification in the Mediterranean and Middle Asian regions, followed by repeated intercontinental dispersal events (Figs. 4, 5). Despite considerable morphological variation and the presumed role of this organ in seed dispersal in Compositae, the pappus of Cardueae does not seem to function as an effective long-dispersal mechanism, because the pappus is often too small, or if large, it is deciduous (Susanna and Garcia-Jacas, 2007). Hence, the present widespread distribution of Cardueae is more likely due to short or medium-distance migration events and rarely to long-distance dispersal (except in the cases of colonization of oceanic islands like Rhaponticum australe in Japan, Cheirolophus Cass. in Macaronesia, and Centaurodendron in the Juan Fernández Islands). Given the large confidence intervals for some divergence time estimates (Fig. 3, Appendix S4), the following discussion will only focus on major biogeographic patterns and/or events. Nevertheless, the spatiotemporal framework given here (Fig. 4) will provide a valuable basis for further studies focusing on specific clades of Cardueae.

Origin in West Asia and Mediterranean diversification (Fig. 4)_The origin of the tribe Cardueae was inferred to be in West Asia around the Middle Eocene (node 7, Fig. 4). This date is much older than those suggested in other molecular studies, in which the stem age of the tribe is estimated as ca. 29-24 Ma (Kim et al., 2005). Indeed, our dating corresponds to the oldest age among tribes of Compositae: $23 \mathrm{Ma}$ in Anthemideae (Oberprieler, 2005), $28 \mathrm{Ma}$ in Cichorieae (Zhang et al., 2011), 34.5 Ma in Gnaphalieae (Bergh and Linder, 2009), while Kim et al. (2005) date the radiation of Compositae tribes as Oligocene in age. This difference in age might be attributed to the existence of a better calibration point provided by the recent discovery of an Eocene fossil of Compositae in South America (Barreda et al., 2010b, 2012). Though a Palaeogene fossil record exists (Barreda et al., 2010b), it is sparse and thus not suitable for calibrating a phylogenetic tree, so the Eocene fossil of Barreda et al. (2010b) is the oldest fossil of Compositae available at the moment.

Our reconstruction indicates that ancestors of Cardueae dispersed from Africa to West Asia, probably via stepping-stones along the Tethyan coast. The most probable dispersal route is across northeastern Africa (Fig. 4A), since all western Mediterranean Cardueae lineages were inferred to have a west Asian origin. Nevertheless, a dispersal event through the Iberian plate cannot be ruled out, since the position of the African plate with regard to Iberia has remained stable for the last $65 \mathrm{Myr}$ (Meulenkamp and Sissingh, 2003; Fig. 4A). Phylogenetic studies in other angiosperm groups have also indicated a West Asian origin for clades that, like Cardueae, are species-rich in the Mediterranean Basin, e.g., Campanula L. (Roquet et al., 2009), Arum L. (Espíndola et al., 2010); Loliinae (Inda et al., 2008). Quézel (1985) also stresses the importance of West Asian (IranoTuranian) elements in the Mediterranean flora, which presumably invaded the Mediterranean Basin in several waves from the Eocene onward.

The first divergence event, splitting Cardopatiinae from the rest of subtribes, was dated as Middle Eocene (node 7, Fig. 3). The facts that the two genera included in this subtribe, Cardopatium Juss. and Cousiniopsis Nevski, are monotypic, and that they have disjunct distributions, suggests that Cardopatiinae could be a palaeoendemic group (sensu Stebbins and Major, 1965), a relict of a former widespread distribution. Cardopatium corymbosum is a perennial, ruderal species that does not extend westward beyond Tunisia (North Africa), and is limited in Europe to Sicily and Greece. Cousiniopsis atractylodes is an annual herb adapted to the deserts of Middle Asia. A perennial habit is probably the ancestral state of Cardopatiinae, as has been suggested for the entire tribe Cardueae (Ortiz et al., 2009). The aridification of Middle Asia during the Oligocene-Miocene transition (Tang et al., 2011) triggered the formation of dry steppe and semidesert landscapes with abundant herbaceous xerophytes, and this could have favored the adaptation of Cousiniopsis to this new habit.

The geographic origin of subtribe Carlininae (node 3, Fig. 4) was uncertain, whereas initial diversification in the remaining subtribes (Echinopsinae, Carduinae, and Centaureinae) was inferred to have occurred in West Asia (nodes 4-6, respectively, Fig. 4), followed by repeated dispersal events across the Mediterranean region. Many of these events were dated to the Oligocene-Miocene period, when additions of microplates located between the Paratethys and Tethys formed a continuous landmass across the Mediterranean, which connected the West Mediterranean Basin with the West Asia-eastern Mediterranean region (Meulenkamp and Sissingh, 2003). This landmass might have enabled the dispersal/migration of Cardueae along the Mediterranean basin (Fig. 4B). Thompson (1999) point out the importance of Late Miocene tectonic movements in explaining Mediterranean plant disjunctions. Oosterbroek and Arntzen (1992) suggest a similar connection pattern to explain the East-West Mediterranean disjunctions of several animal groups. In our analysis, repeated expansions to the East Mediterranean Basin and Central Europe in the Oligocene-Miocene were inferred for subtribes Carduinae (nodes 8-10, Fig. 4) and Carlininae (nodes 11-12, Fig. 4).

The Messinian Salinity Crisis (MSC, 5.96-5.33 Ma; Duggen et al., 2003) is another period for which trans-Mediterranean dispersal of several plant groups has been suggested (Thompson, 1999). During this time, climate aridification and the closing of 
the Gibraltar Strait caused a general drop of sea level in the Mediterranean Basin, allowing species to reach areas previously isolated by sea barriers (Fig. 4C). Land connections between Iberia and North Africa during the Late Miocene (Fig. 4C) would have allowed migration across North Africa and the eastern Mediterranean for lineages belonging to the "core" Centaureinae (nodes 13-15, Fig. 4). Diversification of Onopordum L. (Carduinae) in the Mediterranean region (node 16, Fig. 4) was dated as Pliocene (Fig. 3), when rapid climate oscillations would have favored migration of these species, some of them weeds, through disrupted habitats.

Dispersal to Africa and Macaronesia-Our analysis suggested that several Cardueae species have migrated secondarily to the mountains of tropical Africa. The Cardueae species that reached Africa are only found in mountain areas of this continent; this may indicate that these species colonized Africa during cooler periods and found refuge in the mountain regions of tropical Africa when the climate started to become arid again. Within Carduinae, Carduus nyassanus and C. keniensis (node 17, Fig. 5A) reached Africa in the Pleistocene (Fig. 3). Similarly, in Echinopsinae (Echinops angustilobus and E. hoehnelii) a dispersal event from West Asia to Central/South Africa or the Horn of Africa (node 18, Fig. 5A) was inferred to have occurred during the Quaternary glaciations.

Paleogeographic reconstruction of the Macaronesia region shows that this archipelago has been available for colonization and for stepping-stone dispersals between continents during a broad time scale (Fernández-Palacios et al., 2011). Cardueae have reached Macaronesia at least twice independently at very different time intervals, as inferred by our analyses. The first relates to Cheirolophus (node 19, Fig. 4) and occurred sometime during the Late Miocene (node 87, Fig. 3). Poor representation of this genus in our analysis and weakly resolved relationships with other groups (Fig. 2) made it difficult to reconstruct the origin and direction of this dispersal event, but previous studies have suggested a North African origin for this genus (Susanna et al., 1999). Apart from Macaronesia, the highest species richness for the genus is found in the western Mediterranean region and North Africa, with one species, $C$. crassifolius occurring in the Central Mediterranean (Malta).

A second dispersal event to Macaronesia was inferred for subtribe Carlininae (node 20, Fig. 4) during the Pleistocene (Fig. 3), in the split between Carlina falcata (endemic to the island of La Palma) and C. lanata (widely distributed in the Mediterranean basin). Lower sea levels associated with the Quaternary glaciations may have facilitated stepping-stone dispersal events to the Canary Islands (García-Talavera, 1997), probably from North Africa, where other Carlina species are currently distributed.

Expansion to the east: The Himalayan uplift (Fig. 5)-Along with the Mediterranean region, Middle Asia seems to have been a major area of diversification for the Cardueae (Susanna and Garcia-Jacas, 2009), especially for subtribe Carduinae, for which the uplift of the Qinghai-Tibetan plateau (QTP) played a major role. The uplift of the QTP occurred at several periods, commencing with the Early Eocene collision of India with Eurasia (52 to $45 \mathrm{Ma}$; Rowley, 1996). Four major periods of uplift have been proposed: $22-20,15-13,8-7$, and 3.6-1.8 Ma (Wang et al., 2009 and references therein). Intense orogenic activity would have led to the isolation of populations in valleys and the formation of new habitats on the slopes and peaks of the mountains, which, in turn, contributed to the diversification of plant groups in this region via allopatric speciation. The aridification process triggered by the retreat of the Paratethys Sea (Tang et al., 2011), and the shadow effect created by the uplift of the high Asian plateaus and mountains (Tibet, Pamir, Tian Shan), would have favored diversification in coldand dry-adapted taxa, such as Cardueae.

Dispersal events from West Asia to Middle Asia were inferred in all five subtribes. In Carlininae, a range expansion to Middle Asia and Japan was reconstructed for the Late EoceneEarly Oligocene (node 3, Fig. 5B). This migration event is more likely to have followed a northern route (through the North Caspian Sea) before the uplift of the Pamir Mountains, with later extinction of these xeric adapted taxa in cold latitude areas. Another option is a southern route using the Iranian connection because no basally diverging Carlininae species occur in Southwest Asia (e.g., the Kopet-Dag Mountains), where more xeric habitats occur.

The Arctium and the Cousinia-Jurinea-Saussurea clades recovered in our phylogenetic analysis were reconstructed to have originated in Middle Asia in the Oligocene-Miocene (nodes 21-23, Fig. 4), with divergence of Arctium around the Early Miocene (Fig. 3). This is considerably older than previous estimates, which placed the origin of this genus around the Late Miocene (9.68 Ma; López-Vinyallonga et al., 2009), and can be explained by differences in dating methods: the study by López-Vinyallonga et al. (2009) applied a strict molecular clock approach calibrated with ITS substitution rates, whereas here we used a fossil-calibration molecular-dating approach. Arctium (previously known as arctioid Cousinia species; López-Vinyallonga et al., 2011) includes narrow endemics in the Tian Shan Mountains of Middle Asia, which present character states in pollen morphology and chromosome number that are considered plesiomorphic within the Cousinia group (López-Vinyallonga et al., 2009). The several periods of uplift of QTP during the Middle-Late Miocene might have triggered the diversification of the Arctium group (Fig. 5B), which contains species adapted to cold and dry habitats. The Late Miocene age of Cousinia estimated here (Fig. 3) agrees well with the estimations of López-Vinyallonga et al. (2009), who dates the origin of Cousinia to 8.72 Ma. The date inferred for initial diversification of this genus-one of the largest in Compositae with ca. 500 species - within the IranoTuranian phytogeographical region agrees with the geological events, because the uplifting of mountain belts in the borders of the Iranian plateau during the rapid QTP uplift took place in the Late Miocene (ca. 8 Ma; Zhang and Fritsch, 2010), following the collision of the Indian and Eurasian plates (Dercourt et al., 1986).

Within Carduinae, the split of the Himalayan endemic Xanthopappus (node 24, Fig. 5B) was dated to the Middle Miocene (Fig. 3) and is probably associated with the Miocene QTP uplift some 15-13 Ma (Harrison et al., 1992; Spicer et al., 2003; Fig. 5B). Wang et al. (2007) postulate a similar hypothesis, but their molecular dating analysis estimates a younger age for Xanthopappus (5.7-4.7 Myr), probably because they used ITS substitution rate to date their tree instead of fossil calibration. Migration from West Asia to the Himalayas in the Echinopsinae clade (node 25, Fig. 5B) was date to the Quaternary (Fig. 3). The most recent period of uplift of the Qinghai-Tibetan Plateau that occurred sometime between 3.6-1.8 Ma (Zhang and Fritsch, 2010) may have favored diversification in this clade (Fig. 5B). 

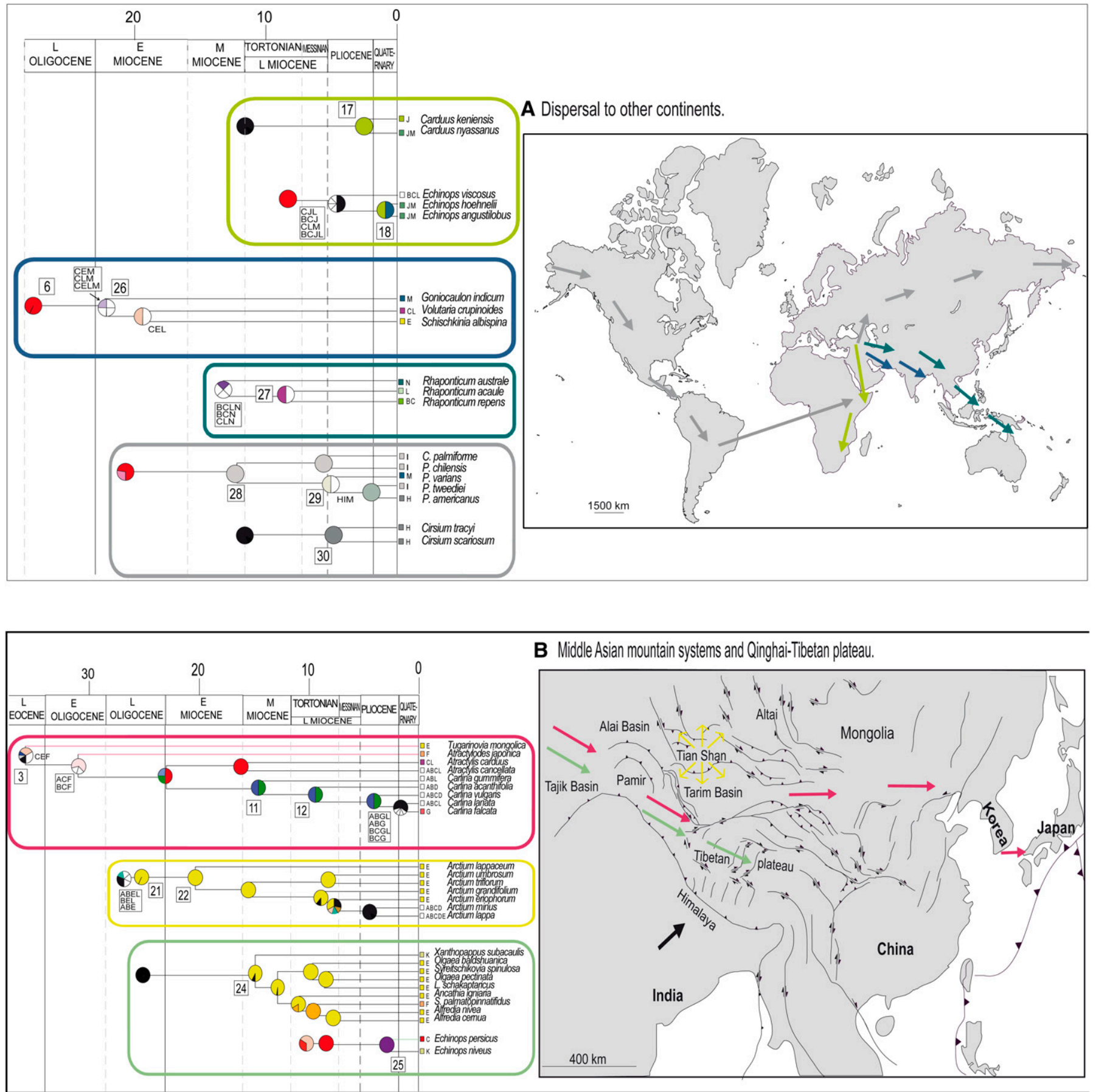

Fig. 5. Biogeographic scenarios showing inferred (A) intercontinental dispersal events and (B) radiation events in Middle Asia and the Qinghai-Tibetan plateau to explain the spatiotemporal evolution of Cardueae during the Cenozoic. The color of arrows corresponds to the colors of the clade frames. Maps redrawn after Yin and Harrison (2000) and De Grave et al. (2007). Key and abbreviations for pie charts and ancestral area probabilities are as in Fig. 4.

Only two genera of Centaureinae, Goniocaulon and Tricholepis DC., are present in South and Southeast Asia (India and Burma). Both belong to the Volutaria group, sister-group to the remaining Centaureinae. Goniocaulon was reconstructed to have migrated in the Early Miocene (Fig. 3) from West Asia (node 26, Fig. 5A), before the closing of this route by the uplifting of the Himalayas. A remarkable migration event from the East Mediterranean/West Asia to Australia dated to the Mid Miocene (Fig. 3) may explain the distribution of the only Centaureinae species native to Australia, Rhaponticum australe (node 27, Fig. 5A). The presence in China, Mongolia, Korea, and Japan of $R$. uniflorum, sister species to $R$. australe (Hidalgo et al., 2006), suggests that this long-distance dispersal was mediated via Middle and East Asia (Fig. 5A). Migration from Southeast Asia to Australia was possible after the collision of the Asian and Australian plates in the Miocene, which led to the uplift of high mountain chains along Malaysia, 
northeastern Australia, and the Highlands of New Guinea, and the onset of a drying trend that enabled the colonization of temperate taxa along the newly created montane habitats (Sanmartín, 2002).

Colonization of the New World: Long-distance dispersal or land-based migration? (Fig. 5)-Floristic exchanges between North America and Asia were possible until about 3.5 Ma, when the Bering Land Bridge (BLB) ceased to be available as a land connection, but were re-established during the Pleistocene during glaciations periods (Wen, 1999; Sanmartín et al., 2001). Two dispersal events to the New World were inferred in our analyses. The first one is inferred for the Plectocephalus group (node 28, Fig. 5A), whose main distribution is North and South America, but it is also found in Ethiopia. The closest relatives of Plectocephalus were not resolved in our phylogenetic reconstruction, but Susanna et al. (2011) suggest that the ancestors of this group could have occurred in West and Middle Asia, since its representatives share morphological characters with Psephellus Cass. (distributed in Turkey, the Caucasus, and the Irano-Turanian region) and Phalacrachena Iljin (distributed in Ukraine and Russia). This distribution pattern would indicate migration of Plectocephalus ancestors from West Asia to the New World via the BLB, with posterior extinction occurring in East Asia. Migration of xeromorphic Plectocephalus may have been favored by the formation of xeric habitats in Middle and East Asia following the Late Oligocene-Miocene aridification event (Susanna et al., 2011). The temporal framework of this hypothesis agrees well with our dating analyses, which estimates that Plectocephalus originated in the Middle Miocene (Fig. 3), before the opening of the Bering Strait and coincident with the existence of a land connection between Siberia and northwestern North America (the "second Beringian Land Bridge", Sanmartín et al., 2001). Our reconstruction also suggests the occurrence of a dispersal event from South America to the Horn of Africa-India during the internode leading to the split of $P$. varians (node 29, Fig. 5A), which seems unlikely knowing the origin of this group. A more probable explanation is that the ancestor of $P$. varians migrated from West Asia to East Africa. Differences in life cycle and evolution rates between species could be responsible for the difficulties encountered in elucidating actual phylogenetic and biogeographic relationships within the Plectocephalus group (Susanna et al., 2011).

A second migration event to North America during the Pliocene (Fig. 3) is shown in the clade formed by two eastern North American Cirsium species (C. scariosum and C. tracyi) included in the Carduus-Cirsium group (node 30, Fig. 5A). New World Cirsium lineage has been shown as a monophyletic group by Kelch and Baldwin (2003), indicating a single colonization event of the North American continent by this lineage. Unfortunately, the sister clade to the New World Cirsium clade is not resolved in our analyses, and thus, we are not able to infer the direction of this dispersal, although the origin of the New World clade is probably explained by a migration via the second BLB before its closure (Sanmartín et al., 2001), probably from Middle Asia, where other Cirsium species are found.

\section{LITERATURE CITED}

AKAIKE, H. 1973. Information theory and an extension of the maximum likelihood principle. In B. N. Petrov and F. Csáki [eds.], Second International Symposium on Information Theory, 267-281. Akadémiai Kiadó, Budapest, Hungary.

Anderberg, A. A., F. Ghahremaninejad, and M. Källersjö. 2007. The enigmatic genus Dipterocome. Compositae Newsletter 45: 23-36.
Barreda, V., L. Palazzesi, M. C. Tellería, L. Katinas, and J. V. Crisci. 2010a. Fossil pollen indicates an explosive radiation of basal Asteracean lineages and allied families during Oligocene and Miocene times in the Southern Hemisphere. Review of Palaeobotany and Palynology 160: $102-110$.

Barreda, V. D., L. Palazzesi, L. Katinas, J. V. Crisci, M. C. Tellería, K. Bremer, M. G. Passala, et Al. 2012. An extinct Eocene taxon of the daisy family (Asteraceae): Evolutionary, ecological and biogeographical implications. Annals of Botany 109: 127-134.

Barreda, V. D., L. Palazzesi, M. C. Tellería, L. Katinas, J. V. Crisci, K. Bremer, M. G. Passalia, ET AL. 2010b. Eocene Patagonia fossils of the daisy family. Science 329: 1621.

Bentham, G. 1873. Compositae. In G. Bentham and J. D. Hooker [eds.], Genera plantarum, 162-533. Lovell Reeve, London, UK.

Bergh, N. G., AND H. P. Linder. 2009. Cape diversification and repeated outof-southern-Africa dispersal in paper daisies (Asteraceae-Gnaphalieae). Molecular Phylogenetics and Evolution 51: 5-18.

Britton, T., C. L. ANDERSon, D. JACQuet, S. LundqVist, AND K. BREMER. 2007. Estimating divergence times in large phylogenetic trees. Systematic Biology 56: 741-752.

Buerki, S., F. Forest, N. Alvarez, J. A. A. Nylander, N. Arrigo, and I. SANMARTíN. 2011. An evaluation of new parsimony-based versus parametric inference methods in biogeography: A case study using the globally distributed plant family Sapindaceae. Journal of Biogeography 38 : $531-550$.

CABrera, A. L. 1977. Mutisieae-Systematic review. In V. H. Heywood, J. B. Harborne, and B. L. Turner [eds.], The biology and chemistry of the Compositae, 1039-1066. Academic Press, London, UK.

CAssin, H. 1819. Sur la familie des Synanthérées, contenant les caractères des tribus. Journal de Physique, de Chimie, d'Histoire Naturelle et des Arts 88: 189-204.

Cullings, K. W. 1992. Design and testing of a plant-specific PCR primer for ecological and evolutionary studies. Molecular Ecology 1: 233-240.

De Grave, J., M. M. Buslov, and P. van den Haute. 2007. Distant effects of India-Eurasia convergence and Mesozoic intracontinental deformation in Central Asia: Constraints from apatite fission-track thermochronology. Journal of Asian Earth Sciences 29: 188-204.

Dercourt, J., L. P. Zonenshain, L. E. Ricou, V. G. Kazmin, X. Le Pichon, A. L. Knipper, C. Grandjacquet, et al. 1986. Geological evolution of the Tethys belt from the Atlantic to the Pamirs since the Lias. Tectonophysics 123: 241-315.

Doyle, J. J., AND E. E. Dickson. 1987. Preservation of plant samples for DNA restriction endonuclease analysis. Taxon 36: 715-722.

DRummond, A. J., AND A. RAMBAUT. 2007. BEAST: Bayesian evolutionary analysis by sampling trees. BMC Evolutionary Biology 7: 214.

Duggen, S., K. Hoernle, P. Van Den Bogaard, L. Rupke, and J. P. Morgan. 2003. Deep roots of the Messinian salinity crisis. Nature 422: 602-606.

Eldenäs, P., M. KÄLlersjö, ANd A. A. Anderberg. 1999. Phylogenetic placement and circumscription of tribes Inuleae s. str. and Plucheeae (Asteraceae): Evidence from sequences of chloroplast gene $n d h F$. Molecular Phylogenetics and Evolution 13: 50-58.

Espíndola, A., S. Buerki, M. Bedalov, P. Küpfer, and N. Alvarez. 2010. New insights into the phylogenetics and biogeography of Arum (Araceae): Unravelling its evolutionary history. Botanical Journal of the Linnean Society 163: 14-32.

Farris, J. S., M. KällersJö, A. G. Kluge, and C. Bult. 1995a. Testing significance of incongruence. Cladistics 10: 315-319.

Farris, J. S., M. Källersjö, A. G. Klugge, and C. Bult. 1995b. Constructing a significance test for incongruence. Systematic Biology 44: 570-572.

Fay, M. F., C. Bayer, W. S. Alverson, A. Y. de Bruijn, and M. W. Chase. 1998. Plastid $r b c L$ sequence data indicate a close affinity between Diegodendron and Bixa. Taxon 47: 43-50.

Felsenstein, J. 1978. Cases in which parsimony or compatibility methods will be positively misleading. Systematic Zoology 27: 401-410.

Felsenstein, J. 1985. Confidence limits on phylogenies: An approach using the bootstrap. Evolution 39: 783-791. 
Fernández-Palacios, J. M., L. de Nascimento, R. Otto, J. D. Delgado, E. García-del-Rey, J. R. Arévalo, and R. J. Whittaker. 2011. A reconstruction of Palaeo-Macaronesia, with particular reference to the long-term biogeography of the Atlantic island laurel forests. Journal of Biogeography 38: 226-246.

Funk, V. A., A. Susanna, T. F. Stuessy, and H. Robinson. 2009. Classification of Compositae. In V. A. Funk, A. Susanna, T. F. Stuessy, and R. J. Bayer [eds.], Systematics, evolution, and biogeography of Compositae, 171-189. International Association for Plant Taxonomy, Vienna, Austria.

Garcia-Jacas, N., M. Galbany-Casals, K. Romaschenko, and A. Susanna. 2008. On the conflicting generic delineation in the Onopordum group (Compositae, Cardueae-Carduinae): A combined nuclear and plastid molecular approach. Australian Systematic Botany 21: 301-311.

Garcia-Jacas, N., T. Garnatje, A. Susanna, and R. Vilatersana. 2002. Tribal and subtribal delimitation and phylogeny of the Cardueae (Asteraceae): A combined nuclear and chloroplast DNA analysis. Molecular Phylogenetics and Evolution 22: 51-64.

Garcia-Jacas, N., A. Susanna, T. Garnatje, and R. Vilatersana. 2001. Generic delimitation and phylogeny of the subtribe Centaureinae (Asteraceae): A combined nuclear and chloroplast DNA analysis. Annals of Botany 87: 503-515.

Garcia-Jacas, N., A. Susanna, and R. Ilarslan. 1996. Aneuploidy in the Centaureinae (Compositae): is $n=7$ the end of the series? Taxon 45: 39-42.

García-Talavera, F. 1997. Las Canarias orientales y la vecina costa africana en el Holoceno. Eres 7: 55-63.

Garnatje, T., S. Garcia, and M. A. Canela. 2007. Genome size variation from a phylogenetic perspective in the genus Cheirolophus Cass. (Asteraceae): Biogeographic implications. Plant Systematics and Evolution 264: 117-134.

Goloboff, P. A., J. S. FARris, And K. Nixon. 2008. TNT, a free program for phylogenetic analysis. Cladistics 24: 774-786.

Greuter, W. 2006-2009. Compositae (pro parte majore). In W. Greuter and E. von Raab-Straube [eds.], Compositae: Euro+Med Plantbasethe information resource for Euro-Mediterranean plant diversity. Website http://www.emplantbase.org/home.html [accessed 30 October 2009].

Häffner, E., And F. H. Hellwig. 1999. Phylogeny of the tribe Cardueae (Compositae) with emphasis on the subtribe Carduinae: An analysis based on ITS sequence data. Willdenowia 29: 27-39.

Hall, T. A. 1999. BioEdit: a user-friendly biological sequence alignment editor and analysis program for Windows 95/98/NT. Nucleic Acids Symposium Series 41: 95-98.

Harrison, T. M., P. Copeland, W. S. F. Kidd, and A. Yin. 1992. Raising Tibet. Science 255: 1663-1670.

Hidalgo, O., N. Garcia-Jacas, T. Garnatje, and A. Susanna. 2006. Phylogeny of Rhaponticum (Asteraceae, Cardueae-Centaureinae) and related genera inferred from nuclear and chloroplast DNA sequence data: Taxonomic and biogeographic implications. Annals of Botany 97: 705-714.

Hipp, A. L., J. C. Hall, And K. J. Sytsma. 2004. Congruence versus phylogenetic accuracy: Revisiting the incongruence length difference test. Systematic Biology 53: 81-89.

Hoffmann, O. 1894. Compositae. In A. Engler, and K. Prantl [eds.], Die natürlichen Pflanzenfamilien, 324-333. Engelmann, Leipzig, Germany.

Inda, L. A., J. G. Segarra-Moragues, J. Muller, P. M. Peterson, and P. Catalán. 2008. Dated historical biogeography of the temperate Loliinae (Poaceae, Pooideae) grasses in the northern and southern hemispheres. Molecular Phylogenetics and Evolution 46: 932-957.

Kelch, D. G., AND B. G. Baldwin. 2003. Phylogeny and ecological radiation of New World thistles (Cirsium, Cardueae-Compositae) based on ITS and ETS rDNA sequence data. Molecular Ecology 12: 141-151.

Kim, K. J., K. S. ChoI, AND R. K. JANSEn. 2005. Two chloroplast DNA inversions originated simultaneously during the early evolution of the sunflower family (Asteraceae). Molecular Biology and Evolution 22: $1783-1792$.

KIM, K. J., AND R. K. JANSEN. 1995. $n d h F$ sequence evolution and the major clades in the sunflower family. Proceedings of the National Academy of Sciences, USA 92: 10379-10383.
Lidén, M., T. Fukuhara, J. Rylander, and B. Oxelman. 1997. Phylogeny and classification of Fumariaceae with emphasis on Dicentra s. 1., based on the plastid gene rps16 intron. Plant Systematics and Evolution 206: 411-420.

López-Vinyallonga, S., I. Mehregan, N. Garcia-Jacas, O. Tscherneva, A. Susanna, and J. W. Kadereit. 2009. Phylogeny and evolution of the Arctium-Cousinia complex (Compositae, Cardueae-Carduinae). Taxon 58: 153-171.

López-Vinyallonga, S., K. Romaschenko, A. Susanna, and N. GarciaJACAS. 2011. Systematics of the Arctioid group: Disentangling Arctium and Cousinia (Cardueae, Carduinae). Taxon 60: 539-554.

LuNDBERG, J. 2009. Asteraceae and relationships within Asterales. In V. A. Funk, A. Susanna, T. F. Stuessy, and R. J. Bayer [eds.], Systematics, evolution, and biogeography of Compositae, 157-169. International Association for Plant Taxonomy, Vienna, Austria.

MAI, D. H. 1995. Tertiäre Vegetationsgeschichte Europas: Methoden und Ergebnisse. Gustav Fischer Verlag, Jena, Germany.

MAI, D. H. 2001. Die mittelmiozänen und obermiozänen Floren aus der Meuroer und Raunoer Folge in der Lausitz, Teil II: Dicotyledonen. Palaeontographica Abteilung, B, Palaophytologie 257: 35-174.

Meulenkamp, J. E., And W. Sissingh. 2003. Tertiary palaeogeography and tectonostratigraphic evolution of the Northern and Southern Peri-Tethys platforms and the intermediate domains of the African-Eurasian convergent plate boundary zone. Palaeogeography, Palaeoclimatology, Palaeoecology 196: 209-228.

MÜLLER, K. 2006. Incorporating information from length-mutational events into phylogenetic analysis. Molecular Phylogenetics and Evolution 38: 667-676.

Near, T. J., AND M. J. Sanderson. 2004. Assessing the quality of molecular divergence time estimates by fossil calibrations and fossil-based model selection. Philosophical Transactions of the Royal Society B-Biological Sciences 359: 1477-1483.

Notredame, C., D. G. Higgins, and J. Heringa. 2000. T-Coffee: A novel method for fast and accurate multiple sequence alignment. Journal of Molecular Biology 302: 205-217.

Nylander, J. A. A. 2004. MrModeltest, version 2. Program distributed by the author. Evolutionary Biology Centre, Uppsala University, Uppsala, Sweden.

Nylander, J. A. A., U. Olsson, P. Alström, and I. Sanmartín. 2008. Accounting for phylogenetic uncertainty in biogeography: A Bayesian approach to dispersal-vicariance analysis of the thrushes (Aves: Turdus). Systematic Biology 57: 257-268.

Oberprieler, C. 2005. Temporal and spatial diversification of CircumMediterranean Compositae-Anthemideae. Taxon 54: 951-966.

Olmstead, R. G., H. J. Michaels, K. M. Scott, and J. D. Palmer. 1992. Monophyly of the Asteridae and identification of their major lineages inferred from DNA-sequences of $r b c L$. Annals of the Missouri Botanical Garden 79: 249-265.

Oosterbroek, P., And J. W. Arntzen. 1992. Area-cladograms of circumMediterranean taxa in relation to Mediterranean paleogeography Journal of Biogeography 19: 3-20.

Ortiz, S., J. M. Bonifacino, J. V. Crisci, V. A. Funk, H. V. Hansen, D. J. N. Hind, L. Katinas, et al. 2009. The basal grade of the Compositae: Mutisieae (sensu Cabrera) and Carduoideae. In V. A. Funk, A. Susanna, T. F. Stuessy, and R. J. Bayer [eds.], Systematics, evolution, and biogeography of Compositae, 193-213. International Association for Plant Taxonomy, Vienna, Austria.

Palazzesi, L., V. Barreda, and M. C. Tellería. 2009. Fossil pollen grains of Asteraceae from the Miocene of Patagonia: Barnadesioideae affinity. Review of Palaeobotany and Palynology 155: 83-88.

Panero, J. L., AND V. A. Funk. 2008. The value of sampling anomalous taxa in phylogenetic studies: Major clades of the Asteraceae revealed. Molecular Phylogenetics and Evolution 47: 757-782.

Petit, D. P. 1997. Generic interrelationships of the Cardueae (Compositae): A cladistic analysis of morphological data. Plant Systematics and Evolution 207: 173-203.

Popescu, S. M. 2002. Repetitive changes in Early Pliocene vegetation revealed by high-resolution pollen analysis: Revised cyclostratigraphy of southwestern Romania. Review of Palaeobotany and Palynology 120: 181-202. 
QuÉzeL, P. 1978. Analysis of the flora of Mediterranean and Saharan Africa. Annals of the Missouri Botanical Garden 65: 479-534.

QuÉzel, P. 1985. Definition of the Mediterranean region and the origin of its flora. In C. Gómez-Campo [ed.], Plant conservation in the Mediterranean area, 9-24. Junk, Dordrecht, Netherlands.

Quicke, D. L. J., O. R. Jones, And D. R. Epstein. 2007. Correcting the problem of false incongruence due to noise imbalance in the incongruence length difference (ILD) test. Systematic Biology 56: 496-503.

Ree, R., and I. Sanmartín. 2009. Prospects and challenges for parametric models in historical inference. Journal of Biogeography 36 : $1211-1220$

RonQUiST, F. 1996. DIVA, version 1.1 Computer program available by anonymous ftp. Uppsala University, Uppsala, Sweden.

RonQuist, F. 1997. Dispersal-vicariance analysis: A new approach to the quantification of historical biogeography. Systematic Biology 46: 195-203.

Ronquist, F., AND J. P. Huelsenbeck. 2003. MrBayes 3: Bayesian phylogenetic inference under mixed models. Bioinformatics 19: 1572-1574.

Roquet, C., I. Sanmartín, N. Garcia-Jacas, L. Sáez, A. Susanna, N. Wikstrom, and J. J. Aldasoro. 2009. Reconstructing the history of Campanulaceae with a Bayesian approach to molecular dating and dispersal-vicariance analyses. Molecular Phylogenetics and Evolution 52: $575-587$.

Rowley, D. B. 1996. Age of initiation of collision between India and Asia: A review of stratigraphic data. Earth and Planetary Science Letters 145: 1-13.

Sánchez-Jiménez, I., G. A. Lazkov, O. Hidalgo, and T. Garnatje. 2010. Molecular systematics of Echinops L. (Asteraceae, Cynareae): A phylogeny based on ITS and trnL-trnF sequences with emphasis on sectional delimitation. Taxon 59: 698-708.

SANDERSON, M. J. 2002. Estimating absolute rates of molecular evolution and divergence times: A penalized likelihood approach. Molecular Biology and Evolution 19: 101-109.

SANDERSON, M. J. 2003. R8s: Inferring absolute rates of molecular evolution and divergence times in the absence of a molecular clock. Bioinformatics 19: 301-302.

Sanmartín, I. 2002. A paleogeographic history of the southern hemisphere. Available at Digital.CSIC: http://hdl.handle.net/10261/34831 [accessed 20 October 2010].

Sanmartín, I. 2003. Dispersal vs. vicariance in the Mediterranean: Historical biogeography of the Palearctic Pachydeminae (Coleoptera, Scarabaeoidea). Journal of Biogeography 30: 1883-1897.

SAnMartín, I., H. ENGhoff, and F. RonQuist. 2001. Patterns of animal dispersal, vicariance and diversification in the Holarctic. Biological Journal of the Linnean Society 73: 345-390.

Santos-Gally, R., P. Vargas, AND J. Arroyo. 2011. Insights into Neogene Mediterranean biogeography based on phylogenetic relationships of mountain and lowland lineages of Narcissus (Amaryllidaceae). Journal of Biogeography doi:10.1111/j.1365-2699.2011.02526.x.

Soltis, D. E., P. S. Soltis, T. G. Collier, and M. L. Edgerton. 1991. The Heuchera group (Saxifragaceae): Evidence for chloroplast transfer and paraphyly. American Journal of Botany 78: 1091-1112.

Siter, R. A., N. B. W. Harris, M. Widdowson, A. B. Herman, S. X. Guo, P. J. Valdes, J. A. Wolfe, and S. P. Kelley. 2003. Constant elevation of southern Tibet over the past 15 million years. Nature 421: 622-624.

StebBins, G. L., And J. MaJor. 1965. Endemism and speciation in California flora. Ecological Monographs 35: 1-35.

Susanna, A., M. Galbany-Casals, K. Romaschenko, L. Barres, J. Martín, and N. Garcia-JaCAS. 2011. Lessons from Plectocephalus (Compositae, Cardueae-Centaureinae): ITS disorientation in annuals and Beringian dispersal as revealed by molecular analyses. Annals of Botany 108: 263-277.

Susanna, A., and N. Garcia-Jacas. 2007. Tribe Cardueae. In J. W. Kadereit and C. Jeffrey [eds.], Flowering plant: Eudicots, Asterales, vol. VIII. In K. Kubitzki [ed.], The families and genera of vascular plants, 123-146. Springer Verlag, Berlin, Germany.

Susanna, A., AND N. Garcia-JaCAs. 2009. Cardueae (Carduoideae). In V. A. Funk, A. Susanna, T. F. Stuessy, and R. J. Bayer [eds.], Systematics, evolution, and biogeography of Compositae, 293-313. International Association for Plant Taxonomy, Vienna, Austria.

Susanna, A., N. Garcia-Jacas, O. Hidalgo, R. Vilatersana, and T. Garnatje. 2006. The Cardueae (Compositae) revisited: Insights from ITS, $\operatorname{trnL}$-trnF, and mat $K$ nuclear and chloroplast DNA analysis. Annals of the Missouri Botanical Garden 93: 150-171.

Susanna, A., N. Garcia-Jacas, D. E. Soltis, and P. S. Soltis. 1995. Phylogenetic relationships in tribe Cardueae (Asteraceae) based on its sequences. American Journal of Botany 82: 1056-1068.

Susanna, A., T. Garnatje, and N. Garcia-Jacas. 1999. Molecular phylogeny of Cheirolophus (Asteraceae: Cardueae-Centaureinae) based on ITS sequences of nuclear ribosomal DNA. Plant Systematics and Evolution 214: 147-160.

SwofFord, D. L. 2002. PAUP*: Phylogenetic analysis using parsimony (*and other methods), version 4.0b10. Sinauer, Sunderland, Massachusetts, USA.

Takhtajan, A. 1986. Floristic regions of the world. University of California Press, Berkeley, California, USA.

Tang, Z. H., Z. L. Ding, P. D. White, X. X. Dong, J. L. Ji, H. C. Jiang, P. Luo, AND X. WANG. 2011. Late Cenozoic central Asian drying inferred from a palynological record from the northern Tian Shan. Earth and Planetary Science Letters 302: 439-447.

Thompson, J. D. 1999. Population differentiation in Mediterranean plants: Insights into colonization history and the evolution and conservation of endemic species. Heredity 82: 229-236.

Vilatersana, R., N. Garcia-Jacas, T. Garnatje, J. Molero, G. Sonnante, and A. Susanna. 2010. Molecular phylogeny of the genus Ptilostemon (Compositae: Cardueae) and its relationships with Cynara and Lamyropsis. Systematic Botany 35: 907-917.

Vilatersana, R., A. Susanna, N. Garcia-Jacas, and T. Garnatje. 2000. Generic delimitation and phylogeny of the Carduncellus-Carthamus complex (Asteraceae) based on ITS sequences. Plant Systematics and Evolution 221: 89-105.

WagenitZ, G. 1976. Systematics and phylogeny of Compositae (Asteraceae). Plant Systematics and Evolution 125: 29-46.

WAHLBERG, N. 2006. That awkward age for butterflies: Insights from the age of the butterfly subfamily Nymphalinae (Lepidoptera: Nymphalidae) Systematic Biology 55: 703-714.

Wang, Y. J., J. Q. Liu, AND G. Miehe. 2007. Phylogenetic origins of the Himalayan endemic Dolomiaea, Diplazoptilon and Xanthopappus (Asteraceae: Cardueae) based on three DNA regions. Annals of Botany 99: 311-322.

Wang, Y. J., A. Susanna, E. von Raab-Straube, R. Milne, and J. Q. Liu. 2009. Island-like radiation of Saussurea (Asteraceae: Cardueae) triggered by uplifts of the Qinghai-Tibetan Plateau. Biological Journal of the Linnean Society 97: 893-903.

Wen, J. 1999. Evolution of eastern Asian and eastern North American disjunct distributions in flowering plants. Annual Review of Ecology and Systematics 30: 421-455.

Wolfe, K. H., W. H. Li, and P. M. Sharp. 1987. Rates of nucleotide substitution vary greatly among plant mitochondrial, chloroplast, and nuclear DNAs. Proceedings of the National Academy of Sciences, USA 84: 9054-9058.

Yin, A., AND T. M. Harrison. 2000. Geologic evolution of the HimalayanTibetan orogen. Annual Review of Earth and Planetary Sciences 28: 211-280.

Zavada, M. S., and S. E. De Villiers. 2000. Pollen of the Asteraceae from the Paleocene-Eocene of South Africa. Grana 39: 39-45.

ZaVADA, M. S., AND T. K. Lowrey. 2010. Comparative pollen morphology of Brachylaena, Tarchonanthus and two species of Tubulifloridites (Asteraceae) from the Eocene, Knysna Lignite of South Africa. Review of Palaeobotany and Palynology 162: 183-192.

Zhang, J.-W., Z.-L. NiE, J. Wen, AND H. Sun. 2011. Molecular phylogeny and biogeography of three closely related genera, Soroseris, Stebbinsia, and Syncalathium (Asteraceae, Cichorieae), endemic to the Tibetan Plateau, SW China. Taxon 60: 15-26.

Zhang, M.-L., AND P. W. FRITSCh. 2010. Evolutionary response of Caragana (Fabaceae) to Qinghai-Tibetan Plateau uplift and Asian interior aridification. Plant Systematics and Evolution 288: 191-199. 